\title{
PROSPEKTÍV EMLÉKEZET ÉS TRAUMÁS AGYSÉRÜLÉS: SZAKIRODALMI ÁTTEKINTÉS
}

\author{
LENCSÉS ANITA ${ }^{1}$ - DEMETER GYULA ${ }^{1,2}$ \\ ${ }^{1}$ Budapesti Múszaki és Gazdaságtudományi Egyetem, Kognitív Tudományi Tanszék \\ ${ }^{2}$ Országos Orvosi Rehabilitációs Intézet, Agysérültek Rehabilitációs Osztálya \\ E-mail: alencses@cogsci.bme.hu
}

Benyújtva: 2020. június 30. - Elfogadva: 2020. december 4.

\begin{abstract}
Jelen tanulmány tudomásunk szerint az elsố magyar nyelvú áttekintés a prospektív emlékezet (prospective memory, PM) témájában, melynek kettôs célja van. Egyrészt összefoglalja a PM legfontosabb fogalmait, elméleteit, kisérleti és idegtudományi eredményeit, ismertetve a kutatások klinikai relevanciáját. A PM a jövốbeli szándékokra irányuló emlékezet, egy olyan összetett kognitív képesség, amely alapvetô a mindennapi feladataink ellátása során. Müködése a prefrontális kéreghez és kapcsolataihoz köthetố, igy számos, a frontostriatális rendszert érintô kórkép esetén sérülést mutat. Áttekintésünk fókuszában egy gyakori neurológiai kórkép, a traumás agysérülés áll. E személyek hétköznapjait a leginkább megnehezító, gyakori és tartós kognitív zavar a PM sérülése. Ennek ellenére kevés kutatás foglalkozott a csökkent PM-múködést meghatározó tényezókkel ebben a betegcsoportban, az eredmények pedig ellentmondásosak.

Tanulmányunk további célja, hogy összefoglalja a traumás agysérült személyek PM-teljesítményével kapcsolatos empirikus kutatásokat. Szakirodalmi áttekintésünkben 25 empirikus tanulmányt azonosítottunk, amelyekben traumás agysérült felnôtt személyek PM-teljesítményét hasonlították össze egészséges kontrollszemélyekével. Az eredmények alapján megállapitható, hogy traumás agysérülést követôen jellemzố a PM diszfunkciója. Azonban számtalan tényezô befolyásolhatja a PM-teljesítményt ebben a populációban: a sérülés súlyossága, lokalizációja, a kómában és a poszttraumás amnéziában töltött idô, a sérülés óta eltelt idô, a hangulatzavarok és a komorbid kognitív zavarok; valamint az olyan feladatjellemzók, mint a méróeszköz típusa, a PM összetevôi, illetve a prospektív kulcsinger és a folyamatban lévó feladat jellegzetességei.

Elgondolásunk szerint e kutatási eredmények nemcsak a PM múködésének megértésével kapcsolatban szolgálnak fontos következtetésekkel, hanem támpontokat adhatnak a rehabilitációs, terápiás munkára nézve is, megteremtve egy jövóbeli hatékony, a PM-funkciókra fókuszáló kognitív tréning kidolgozását traumás agysérült személyek számára.
\end{abstract}

Kulcsszavak: prospektív emlékezet, szándékok kivitelezése, traumás agysérülés, rehabilitáció 


\section{A PROSPEKTÍV EMLÉKEZET FOGALMA ÉS FONTOSABB ELMÉLETEI}

A prospektív emlékezet (prospective memory, PM) az a képességünk, amely lehetôvé teszi, hogy egy szándékot megốrizzünk, felelevenítsünk, és a jövô egy adott idôpontjában és kontextusában kivitelezzünk (Meacham és Dumitru, 1976). Ez az emlékezeti rendszer szükséges mindennapi életünk legalapvetôbb feladatainak ellátásához; úgymint a találkozók észben tartása, gyógyszerek szedése vagy a bevásárlás intézése, hogy csak egy pár alapvetô példát említsünk.

Minden PM-feladat magában foglal egy prospektív és egy retrospektív összetevôt. A retrospektív összetevố magának a szándéknak a tartalma, az arra való emlékezés, hogy mit kell végrehajtanunk; míg a prospektív összetevő arra vonatkozik, hogy képesek vagyunk ezt az elôre meghatározott cselekvést a jövố megfelelố pillanatában végrehajtani, azaz az arra való emlékezés, hogy mikor kell kiviteleznünk a szándékunkat (Kvavilashvili, 1987). Egy hétköznapi példával: ha valakinek van egy olyan szándéka, hogy este 6-kor be kell vennie a gyógyszerét, akkor ez esetben a prospektív összetevó az este 6, míg a retrospektív összetevố az arra való emlékezés, hogy milyen gyógyszert kell bevenni. A PM sérült múködését a két összetevô érintettsége együttesen, de külön-külön is okozhatja. Az, hogy nem sikerül egy jövôbeli szándéknak a végrehajtása, magyarázható azzal, hogy a személy nem emlékszik arra a specifikus cselekvésre, amelyet végre kell hajtania (retrospektív összetevô sérülése), valamint azzal is, hogy nem sikerült asszociatív kapcsolatot kialakítania a célesemény és a szándék között (prospektív összetevô sérülése) (Carlesimo, Casadio és Caltagirone, 2004). Az elôbbi példánál maradva, a gyógyszer bevételének elmulasztását magyarázhatjuk azzal is, hogy bár a személynek eszébe jutott, hogy este 6-kor valamit csinálnia kell, de arra nem emlékezett, hogy pontosan mi az; illetve azzal is, hogy bár emlékezett arra, hogy be kell vennie a gyógyszerét, azt nem tudta, hogy milyen idôpontban kell ezt megtennie. A fentebb említett példa a PM-zavarok egyik gyakran vizsgált aspektusát, a kihagyásokat szemlélteti, emellett azonban abnormális PM-múködésnek tekinthetjük az ismétléseket is (Scullin, Bugg és McDaniel, 2012). A PM retrospektív összetevôje ugyanis azt is magában foglalja, hogy emlékszünk arra, hogy a szándékunkat már megvalósítottuk, és így azt nem hajtjuk újból végre. A retrospektív összetevô sérülése esetén azonban előfordulhat, hogy egy személy nem emlékszik arra, hogy már bevette az aznapi gyógyszeradagját, ezért azt újra és újra beveszi, ami súlyos egészségügyi következményekkel járhat (Scullin és mtsai, 2012).

Habár a prospektív emlékezetre a szakirodalom általában egy egységes elméleti konstruktumként hivatkozik, a PM valójában inkább egy ernyôfogalom, amelynek múködése több különbözô kognitív funkciótól függ, és több eltérố típusú feladatban is megnyilvánulhat (Ellis és Freeman, 2008). Az a hívóinger, amely a jövôbeli szándék végrehajtására figyelmezteti a személyt, a prospektív kulcsinger, melynek jellege alapján a PM-feladatoknak több típusát különböztetjük meg. Eseményalapú PM-feladatról van szó abban az esetben, ha egy cselekvést egy elốre meghatározott esemény bekövetkeztekor kell végrehajtani, például átadni egy barátunknak egy üzenetet akkor, amikor találkozunk vele. Az idôalapú PM arra vonatkozik, amikor a szándékot a jövó egy meghatározott idôpontjában, vagy egy bizonyos idô elteltével kell elvégezni, például reggel 9-kor felhívni telefonon a bankot (McDaniel és Einstein, 2000). Az idô- és ese- 
ményalapú PM-feladatok mellett beszélhetünk egy harmadik típusról, a cselekvésalapú PM-feladatról is: ez esetben a jövôbeli szándékot egy bizonyos cselekvésnek a befejeztével kell megtenni, például kikapcsolni a sütôt, miután elkészült az étel (Kvavilashvili és Ellis, 1996). A szándékolt cselekvés gyakoriságának szempontjából a PM-feladatoknak másik két típusát is megkülönböztethetjük: a szokásalapú PM-feladatokat, melyeket meghatározott idôközönként (pl. naponta, hetente) kell elvégezni, illetve az epizodikus PM-feladatokat, melyek olyan egyedi eseményeket takarnak, amelyeket jellemzốen csak egyszer, egy meghatározott idôpontban vagy kontextusban kell végrehajtani (Meacham és Singer, 1977). További típusait különböztetjük meg a PM-feladatoknak az alapján, hogy ki az, aki megfogalmazza a szándékot: ez alapján beszélhetünk mások által megfogalmazott és önmagunk által megfogalmazott szándékokról (Kvavilashvili, 1992). A fentebb említett PM-feladattípusok természetesen keveredhetnek is: például egy mások által megfogalmazott epizodikus idôalapú PM-feladat az, ha a fônököm megkér arra, hogy holnap 12-kor vigyem ki a reptérre.

A sikeres PM-teljesítmény hátterében álló folyamatok szerepérôl több elmélet is született. A két legismertebb elmélet a prospektív emlékezettel kapcsolatban az automatikus, illetve a stratégiai folyamatok szerepét hangsúlyozza. A többszörös folyamatok elmélete (Multiprocess Framework; McDaniel és Einstein, 2000) abból a feltételezésbôl indul ki, miszerint a PM-feladat jellemzőitôl függóen a szándék elôhívása automatikusan, illetve stratégiai folyamatokon keresztül is megvalósulhat. Stratégiai folyamatnak tekinthetô a monitorozás, mely során figyelemmel kísérjük és keressük azokat a kulcsingereket, amelyek jelzik, hogy mikor kell végrehajtanunk a szándékunkat. Az elmélet szerint a monitorozó múködés mellett azonban a prospektív kulcsingerek észlelése bizonyos feltételek mellett automatikusan történik. Automatikus elôhívás történhet abban az esetben, ha a kulcsinger és a szándék között erôs asszociatív kapcsolat áll fenn; a kulcsinger kiugró; illetve akkor, ha a PM-feladattal párhuzamosan végzett, folyamatban lévố feladat kevés kognitív erôforrást igényel, és ezáltal lehetôvé teszi, hogy a figyelem a kulcsinger releváns jellemzôire irányuljon (McDaniel és Einstein, 2000). Az elókészitố figyelmi és emlékezeti folyamatok modellje (Preparatory Attentional and Memory model, PAM; Smith, 2003, 2010) az elóbb említett elmélettel szemben azt feltételezi, hogy egy szándék végrehajtása minden esetben kontrollált figyelmi folyamatokon keresztül történik, melyek a folyamatos monitorozás miatt erôforrás-igényesek. A PAM-modell szerint egy szándék végrehajtása kétféle kognitív folyamatot foglal magában: az elôkészítô figyelmi folyamatokat, melyek a folyamatban lévô feladat során a monitorozó múködést valósítják meg, illetve a retrospektív emlékezeti múködést, amely lehetôvé teszi, hogy megőrizzük és felidézzük a szándékunkban álló cselekvést (Smith, 2003).

A PM vizsgálatára számtalan módszer létezik: naturalisztikus feladatok, laboratóriumi paradigmák, standardizált klinikai mérôeszközök, önjellemzó kérdőívek, illetve újabban videó- és virtuálisvalóság-alapú feladatok. A továbbiakban röviden jellemezzük az egyes vizsgálati eljárásokat, felvázolva néhány példát, illetve arra is kitérünk, hogy az adott módszernek milyen elônyei és hátrányai vannak.

A prospektív emlékezettel foglalkozó legkorábbi kutatások a szándékokra való emlékezés gyakorlati aspektusaira fókuszáltak, és a kísérleti paradigmák helyett elsôsorban a mindennapi életszituációkhoz hasonló feladatokat alkalmaztak (Burgess, 
Gonen-Yaacovi és Volle, 2011). Ezek az ún. naturalisztikus PM-feladatok a mai napig népszerúek, hiszen magas ökológiai validitással rendelkeznek. Egy tipikus példája az ilyen feladatoknak a „Hívj vissza!” feladat (Call-back Task; Rose és mtsai, 2015), melyben a vizsgálati személynek a saját otthonában kell elvégeznie különbözố feladatokat, például vissza kell hívnia telefonon a vizsgálatvezetôt egy előre megadott idôpontban. A naturalisztikus feladatok hátránya, hogy számtalan olyan tényezố lehet, amely befolyásolja az emlékezeti teljesítményt egy ilyen helyzetben: nem bizonyosodhatunk meg például arról, hogy a vizsgálati személy nem használt-e segítségként emlékeztetôket.

A laboratóriumi PM-feladatok elônye, hogy szemben a naturalisztikus, otthoni környezetben végzett feladatokkal, ez esetben különbözó változók manipulálásán, illetve kontroll alatt tartásán keresztül tesztelhetôk az elméleti kérdések és hipotézisek. Hátrányuk azonban, hogy alacsony ökológiai validitással rendelkeznek (Raskin, Williams és Aiken, 2018). A legtöbb laboratóriumi feladat lényegében egy kettôs feladathelyzet: a kísérlet során a résztvevő egy folyamatban lévố feladatot végez, miközben bizonyos idôközönként PM-kulcsingerekre kell reagálnia (McDaniel és Einstein, 2000). A PM-kulcsinger megjelenésekor kell végrehajtania egy előre meghatározott feladatot: a szándék kódolása és végrehajtása között pedig bizonyos késleltetésnek kell eltelnie, mely során a résztvevô a folyamatban lévô feladatot végzi. Folyamatban lévô feladatként használható bármilyen olyan feladat, amely kellô mértékben leterheli a vizsgálati személy figyelmét és kognitív erôforrásait, hogy ezáltal ne tudja az artikulációs tárban folyamatos elôhívással gyakorolni a végrehajtandó szándékot (Burgess és mtsai, 2011; Potvin, Rouleau, Audy, Charbonneau és Giguère, 2011). A prospektív kulcsinger megjelenésekor a résztvevőnek egy elôre meghatározott, az ingerre specifikus választ kell adnia: ezt a folyamatban lévô feladat megszakításával, egy meghatározott időablakban teheti meg.

A fentebb tárgyalt laboratóriumi paradigmák mellett léteznek klinikai orientációjú laboratóriumi PM-feladatok, amelyeknek nagy előnye, hogy egyesítik magukban a naturalisztikus feladatok életszerûségét, illetve a laboratóriumi feladatok kontrollált körülményeit. Egy ilyen széles körben alkalmazott feladat a Virtuális Hét (Virtual Week; Rendell és Henry, 2009), amely egy számítógépes társasjáték formájában a mindennapi életben elooforduló PM-feladatokat szimulálja egy hét teendôinek keretébe ágyazva. Emellett a technika fejlôdésével az elmúlt években lehetôvé vált kontrollált laboratóriumi körülmények között még életszerúbb módon szimulálni a hétköznapi PM-feladatokat: a videó- és virtuálisvalóság-alapú naturalisztikus feladatokban komplex virtuális környezetben kell jövôbeli szándékokat kivitelezni. Ilyen virtuálisvalóság-alapú feladat például a Virtuális Múzeum (Virtual Museum; Rehel és mtsai, 2019), amelyben egy múzeumot a virtuális térben bejárva kell megszemlélni kiállítási tárgyakat és azok kapcsán feladatokat elvégezni; vagy a Virtuális Bevásárlás Feladat (Virtual Reality Shopping Task; Canty és mtsai, 2014), amelyben egy virtuális áruházban kell megvásárolni különbözô termékeket. A virtuálisvalóság-alapú feladatok hátránya azonban, hogy bizonyos személyeknél az eszköz használata során a tengeribetegség tüneteihez hasonló rosszullét, úgynevezett szimulátorbetegség (az angol nyelvú irodalomban simulator sickness, cybersickness vagy VR sickness) léphet fel (Banville és Nolin, 2012).

Szintén a mindennapi életben tapasztalt emlékezeti teljesítményt igyekeznek megragadni az önjellemzô kérdốvek, melyek általában olyan hétköznapi tevékenységre 
kérdeznek rá, melyek prospektív emlékezetet igényelnek. Egyszerúségük és idôhatékonyságuk mellett az ilyen tesztek elônye továbbá, hogy ezeken keresztül információt nyerhetünk a vizsgálati személy metamemóriájáról: megérthetjük azt, hogy ô szubjektív módon hogyan észleli a mindennapok során felmerüló emlékezeti problémáit. A kérdôíves módszer hátránya azonban, hogy eredménye általában nem jár együtt más PM-mérôeszközökön mutatott teljesítménnyel (Raskin és mtsai, 2018). A PM felmérésére alkalmas kérdốivek közé tartozik a Prospektív és Retrospektív Emlékezeti Kérdôív (Prospective and Retrospective Memory Questionnaire, PRMQ; Crawford, Smith, Maylor, Della Sala és Logie, 2003), illetve a Prospektív Emlékezet Átfogó Értékelése (Comprehensive Assessment of Prospective Memory, CAMP; Chau, Lee, Fleming, Roche és Shum, 2007).

Bár a klinikai gyakorlatban hasznosak lehetnek a fentebb említett eljárások, a különbözó betegpopulációk PM-teljesítményének felmérése érdekében kidolgoztak standardizált klinikai mérôeszközöket is. Az egyik legismertebb, magyar nyelven is elérhetô klinikai méróeszköz a Rivermead Viselkedéses Memóriateszt (Rivermead Behavioral Memory Test, RBMT; Wilson, Cockburn és Baddeley, 1985; magyar változat Racsmány és Kónya, 1998). Ez a teszt két prospektív alfeladatot tartalmaz: a vizsgálat végeztével emlékezni kell egy elrejtett tárgyra, és vissza kell azt kérni a vizsgálatvezetôtôl (Használati tárgy alfeladat), illetve egy ébresztôóra megszólalásakor fel kell tenni egy előre megbeszélt kérdést a vizsgálatvezetônek (Megbeszélt időpont alfeladat). A RBMT magas ökológiai validitással rendelkezik, és kitûnô prediktív erôvel bír, ám túl kevés feladatot tartalmaz ahhoz, hogy átfogó képet adhasson a PM teljesítménybeli különbségeirôl. Épp ezért az RBMT mellett kidolgoztak összetettebb klinikai mérôeszközöket is a PM mérésére: a Cambridge Prospektív Emlékezeti Tesztet (Cambridge Prospective Memory Test, CAMPROMPT; Wilson, Emslie, Foley, Shiel és Watson, 2005) és a Szándékokra Való Emlékezés Szürôtesztet (Memory for Intentions Screening Test, MIST; Raskin, 2004) egyaránt használják a klinikai gyakorlatban. A klinikai mérôeszközök elônye, hogy normatív pontszámokkal rendelkeznek, így a vizsgálati személy teljesítményét össze tudjuk hasonlítani egy meghatározott populáció átlagával. Hátrányként említhetô, hogy sok esetben meglehetôsen idôigényes az ilyen tesztek felvétele (Raskin és mtsai, 2018).

Tanulmányunk elején említettük, hogy a PM egy olyan összetett képesség, amelynek múködéséhez több kognitív funkció is hozzájárul. A PM szempontjából az egyik ilyen legfontosabb funkciónak a végrehajtó múködések tekinthetôk. A prospektív emlékezethez hasonlóan a végrehajtó funkciók is egy ernyőfogalom, amely azokat a kognitív folyamatokat foglalja magában, amelyek a tudatos és célirányos viselkedés megtervezéséért és megvalósításáért felelôsek (Burgess, 1997). Könnyen belátható, hogy egy jövôbeli szándékunk megfelelô idôben és kontextusban történô kivételezéséhez szükségünk van olyan, a végrehajtó funkciókhoz köthetố képességekre, mint a különbözó feladatrészek összehangolása és a fontossági sorrend felállítása, a figyelem megosztása egyszerre több feladat között, adott információk legátlása, a környezet folyamatos monitorozása, továbbá az információ emlékezetben való megtartása és manipulációja (Kliegel, Martin, McDaniel és Einstein, 2002).

A végrehajtó funkcióknak több elméleti modellje is létezik a szakirodalomban (részletes áttekintésért lásd: Rabbitt, 2004). Az utóbbi évek kutatásaiban a leggyakrabban Miyake és munkatársainak (2000) háromfaktoros modelljét vizsgálták, amely frissítés- 
re, gátlásra és váltásra osztja a végrehajtó múködéseket. Egy nemrégiben megjelent kutatás (Spiess, Meier és Roebers, 2015) e modell alapján vizsgálta meg a végrehajtó funkciók kapcsolatát a prospektív emlékezettel. Eredményeik szerint, bár a két fogalom jelentôs átfedésben van egymással kognitív jellemzőik tekintetében, azonban empirikus módon egyértelmúen elkülöníthetôk egymástól már általános iskolás gyerekeknél is.

A két kognitív funkció hasonlóságainak ellenére az azonban továbbra is vitatott, hogy a végrehajtó rendszer milyen mértékben járul hozzá a prospektív emlékezeti múködéshez. Az idegtudományi irodalomban mind a végrehajtó funkciókat, mind a prospektív emlékezetet a prefrontális kéreg múködéséhez és e terület kapcsolataihoz kötik (Miller és Cohen, 2001; Simons, Schölvinck, Gilbert, Frith és Burgess, 2006; Okuda és mtsai, 2007; Burgess és mtsai, 2011), a közös lokalizáció miatt pedig feltételezhetô a két kognitív funkció közötti szoros összefüggés.

Fontos azonban kiemelni, hogy a két funkció kapcsolata sokkal összetettebb, amit számtalan tényezó magyarázhat. Az egyik ilyen tényezó - amelyre Kliegel és munkatársainak eredményei hívták fel a figyelmet - azzal kapcsolatos, hogy az egyes végrehajtó komponensek a PM folyamatának más-más szakaszával járnak együtt. Ugyanis a retrospektív emlékezethez hasonlóan a PM is egy komplex folyamat, mely különbözô szakaszokból áll. Kliegel és munkatársainak (2002) folyamatmodellje alapján a PM négy szakaszra osztható, amelyek különbözô végrehajtó funkciókkal hozhatók kapcsolatba, és megfeleltethetôk a retrospektív emlékezeti folyamat összetevőinek is. A PM elsố szakasza a jövôre vonatkozó szándék megfogalmazása („valamit késôbb tennem kell”), mely a kódolásnak feleltethetô meg. A második szakasz a szándék megốrzése, azaz a megfogalmazott szándék és a végrehajtása között eltelt idô, mely egy tárolási folyamat. A harmadik szakasz a szándék aktiválása, egy olyan elóhívási folyamat, mely során a viselkedési szándékot adott idôben és kontextusban idézzük fel. A negyedik szakasz végül a szándék végrehajtása, avagy a szándékolt viselkedés tényleges kivitelezése. A modell alapján a szándék megfogalmazása a végrehajtó funkciók közül elsôsorban a tervezést foglalja magában, a szándék megórzése retrospektív emlékezeti folyamatokat kíván, a szándék aktiválása monitorozást és gátlást, míg a szándék sikeres végrehajtása kognitív rugalmasságot igényel (Kliegel és mtsai, 2002). A szerzôk egy késôbbi kutatása (Martin, Kliegel és McDaniel, 2003) két másik tényezô szerepére is felhívta a figyelmet: a végrehajtó funkciók hozzájárulása a PM múködéséhez ugyanis erôsen függ az életkortól és attól, hogy milyen PM-feladatot használunk. Eredményeik szerint a végrehajtó funkciókban megfigyelhetô egyéni különbségek csak az idôseknél jósolták be a PM-teljesítményt, és az ô esetükben is csak a komplex PM-feladatra vonatkozóan. Magyarázatuk szerint a végrehajtó funkciók fontossága az életkor elôrehaladtával nô, azonban a PM csak akkor függ erôsen a végrehajtó funkcióktól, amennyiben a feladat összetett, és a fókusz a szándék megfogalmazásán és végrehajtásán van.

Mint már említettük, a végrehajtó funkciók és a PM múködésében is elsôsorban a prefrontális kéreg vesz részt, ugyanakkor a PM szempontjából a prefrontális területen belül a rostrális prefrontális kéregnek (BA10) van kiemelt jelentôsége. E terület emelkedett aktivitást mutat idő- és eseményalapú PM-feladatok végrehajtása során, verbális és nonverbális ingeranyag esetén is (Cona és Rothen, 2019). Burgess, Dumontheil és 
Gilbert (2007) kapuzási elmélete (Gateway Hypothesis) szerint e terület múködése teszi lehetôvé, hogy egyidejûleg figyeljünk a külsố ingerekre és saját belsố gondolatainkra. A kapuzási elmélet a rostrális prefrontális kéreg két alrégióját különíti el azok funkciói alapján: a laterális rész az ingerfüggetlen figyelemért és ezáltal a belsôleg generált szándékok fenntartásáért, míg a mediális rész az ingerorientált figyelemért felelôs, lehetôvé téve egy inger által kiváltott viselkedés végrehajtását. A hipotézis szerint a rostrális prefrontális kéreg laterális és mediális régiói ezáltal egy kapuzási mechanizmust valósítanak meg, amely egyensúlyt teremt a prospektív szándék belsố reprezentációja és a folyamatban lévô feladat külsố ingereire való figyelem között (Burgess és mtsai, 2007). Emellett a rostrális prefrontális kéreg aktivációját a PM kulcsinger jellege is befolyásolja: Okuda és munkatársai (2007) eredményei alapján az eseményalapú PM-feladatoknál a laterális régió emelkedett, míg a mediális csökkent aktivitást mutat; ezzel szemben az idôalapú PM-feladatokban a mediális régió egyes területei aktívak. A rostrális prefrontális kéreg mellett a frontoparietális hálózatoknak szintén jelentôs szerepük van a PM-feladatok végrehajtásában. A figyelem a késleltetett szándékra modell (Attention to Delayed Intention Model, AtoDI; Cona, Scarpazza, Sartori, Moscovitch és Bisiacchi, 2015) a frontoparietális hálózatokat az alapján különíti el, hogy azok a PM melyik szakaszában mutatnak emelkedett aktivitást. Míg a dorzális frontoparietális hálózat elsôsorban a PM-ingerek monitorozásáért és a szándék fenntartásáért felelôs, addig a ventrális frontoparietális hálózat a szándék elóhívásában játszik szerepet. Az említett területeken felül a PM-teljesítmény agyi korrelátumaiként említhetjük még az insulát, az anterior cinguláris kérget, a posterior cinguláris kérget, a temporális területeket, a thalamust, a putament és a kisagyi régiókat is (Cona és Rothen, 2019).

Mivel a PM egészséges múködéséhez több agyterület összehangolt múködése szükséges, nem meglepô, hogy az elmúlt évtizedekben a kutatások fókuszába kerültek olyan neuropszichiátriai és neurodegeneratív kórképek, amelyekben elsôsorban a frontostriatális struktúrák érintettek. A PM kapcsán a legtöbbet kutatott kórképek közé tartozik az Alzheimer-kór (pl. Jones, Livner és Bäckman, 2006), a Parkinson-kór (pl. Costa, Peppe, Caltagirone és Carlesimo, 2008), a sclerosis multiplex (pl. Bravin, Kinsella, Ong és Vowels, 2000), a szkizofrénia (pl. Henry, Rendell, Kliegel és Altgassen, 2007), az obszesszív-kompulzív zavar (pl. Racsmány, Demeter, Csigó, Harsányi és Németh, 2011), a szerfüggôség (pl. Rendell, Gray, Henry és Tolan, 2007), a hangulatzavarok (pl. Rude, Hertel, Jarrold, Covich és Hedlund, 1999), illetve az olyan fejlődési rendellenességek, mint a figyelemzavaros hiperaktivitás (pl. Kerns és Price, 2001) és az autizmus (pl. Altgassen, Williams, Bölte és Kliegel, 2009). E kórképek mindegyikében csökkent PM-múködést figyeltek meg különbözô feladatokkal, és a betegek sok esetben számoltak be a mindennapi tevékenységeiket is érintố tervezési nehézségekrôl (összefoglalásért lásd Kliegel, Jager, Altgassen és Shum, 2012). Áttekintô cikkünk a továbbiakban egy gyakori neurológiai kórkép, a traumás agysérülés kapcsán foglalja össze a prospektív emlékezettel kapcsolatos kutatásokat. Traumás agysérülés esetén a leggyakrabban a frontális és temporális lebenyi területek szenvednek fokális sérülést (Levin és Krauss, 1994); és figyelembe véve, hogy a PM-teljesítmény ezen neurális hálózatok funkcionális integritásán alapul, az agysérült betegek nagy részénél jellemzó a PM zavara. 


\section{TRAUMÁS AGYSÉRÜLÉS ÉS PROSPEKTÍV EMLÉKEZET}

A traumás agysérülés egy olyan szerzett agyi sérülés, amely zárt fejsérülést követôen lép fel: ilyenkor a fejet olyan nagy erejú ütés éri, melynek következményeként az agy erốteljes mozgásba lendül, és megsérülhet a koponya csontos részeinek kidudorodásaitól vagy az idegrostok csavarodásai, szakadásai miatt (WHO, 2006). Ez a szerzett agysérülés meglehetôsen gyakori, becsült incidenciája Európában évente 235/100 ezer fố. A sérülés leggyakoribb okai között szerepelnek a közúti balesetek, az esések, illetve az erőszak (Tagliaferri, Compagnone, Korsic, Servadei és Kraus, 2006). A traumát okozó esemény hatására fellépô sérülés egy két állomásból álló folyamat, mely során megkülönböztetünk elsôdleges, illetve másodlagos sérüléseket. Az elsốdleges sérülések a fejet ért ütéssel egy idôben kezdôdnek, fokális vagy diffúz sérülést okozva az agyban (Crowe, 2008, 17). A zárt fejsérülést követố pár órában az elsôdleges sérüléseket súlyosbíthatja másodlagos sérülések kialakulása: idetartoznak a vérzések, ödémák, vérszegénység, valamint az oxigénhiányos és hiperkapniás állapotok (Crowe, 2008, 19).

A traumás agysérülés hosszú távú következményeit és a várható felépülés kimenetelét a sérülés súlyossága nagymértékben előrejelzi (Brooks, Aughton, Bond, Jones és Rizvi, 1980). A sérüléseket a súlyosság alapján enyhe, mérsékelt és súlyos kategóriákba sorolják. A súlyossági osztályokba való besorolást a Glasgow Kóma Skálán elért pontszám adja, mely egy olyan, a tudatállapot megállapítására szolgáló eszköz az egészségügyi ellátásban, amely az eszméletvesztés fokát és tartósságát a szemnyitás, a verbális, illetve a motoros válaszok minôsége alapján határozza meg (WHO, 2006). A statisztikák alapján az esetek 90\%-a enyhe sérülés, amelyet gyors felépülés követ, míg a fennmaradó 10\%-ot mérsékelt és súlyos esetek teszik ki (Tagliaferri és mtsai, 2006). A Glasgow Kóma Skála mellett a sérülés súlyosságának megállapítására szolgáló másik mutató a poszttraumás amnézia hossza. A poszttraumás amnézia (post-traumatic amnesia, PTA) a traumás agysérülés egyik jellemző szakasza, amely olyan enyhébb fejsérülést követôen is felléphet, mely során nem alakul ki kóma (Levin és Hanten, 2004). A PTA változó hosszúságú - pár perctôl akár több hétig is tarthat -, és jellemzôen figyelemzavarral, dezorientációval és a tanulási képességek nagy fokú romlásával jár (Chen és Batchelor, 2019; Marshman, Jakabek, Hennessy, Quirk és Guazzo, 2013). A különbözô kutatási eredmények vegyes képet mutatnak a PTA-val kapcsolatban. Bár korábbi kutatások szerint a PTA hossza jelzi elôre a legnagyobb valószínúséggel a késốbbi maradandó kognitív és viselkedéses változásokat (Bishara, Partridge, Godfrey és Knight, 1992; Brooks és mtsai, 1980; Haslam és mtsai, 1994), egy friss kutatás eredményei szerint a PTA hossza nem járt együtt a verbális és nonverbális intelligenciával, a munkamemóriával, az azonnali és késletetett felidézéssel, az információfeldolgozás sebességével és a végrehajtó funkciókkal (Chen és Batchelor, 2019).

Az Egészségügyi Világszervezet jelentése alapján a traumás agysérülés vezetố halálok szerte a világon, emellett pedig a rokkantság hátterében álló leggyakoribb ok. A traumát követốn a betegek sokszor évekig munkaképtelenek, ami hatalmas gazdasági hátrányt okoz az egyén, a család és a társadalom szintjén is (WHO, 2006). Ennek ellenére viszonylag kevés kutatás foglalkozott az agysérülés során fellépô neurokognitív károsodásokat meghatározó tényezôkkel, ráadásul az eredmények ellentmondásosak (Chen és Batchelor, 2019). Traumás agysérülést követốn a jellemzó fizikai, viselkedé- 
ses és érzelmi tüneteken felül több kognitív területen is maradandó sérülés alakul ki: leggyakrabban a figyelem, az epizodikus emlékezet, a feldolgozás sebessége és a végrehajtó funkciók érintettek (Chen és Batchelor, 2019; Shum, Levin és Chan, 2011). Míg az emlékezet károsodásával foglalkozó kutatások a deklaratív emlékezeten belül nagyrészt a retrospektív emlékezeti zavarokra koncentráltak, ez idáig felettébb kevés tanulmány foglalkozott a PM-teljesítmény empirikus kutatásával, holott mind a betegek, mind a hozzátartozóik arról számolnak be, hogy a mindennapi életüket legnagyobb mértékben e zavar nehezíti meg (Shum és mtsai, 2011; Wong Gonzalez és Buchanan, 2019). A PM diszfunkciója meglehetôsen negatív hatással van a betegek életminôségére, mivel egy ilyen jellegú kognitív károsodás nemcsak a munkába való visszatérést és az önálló életvitel gyakorlását nehezíti meg, hanem a rehabilitációs programban való részvételt is (Wong Gonzalez és Buchanan, 2019).

Jelen tanulmány célja, hogy összefoglalja a traumás agysérült személyek PM-teljesítményével kapcsolatos empirikus kutatásokat, és ezáltal kiegészítse az elmúlt években a témában megjelent cikkek eredményeit. A traumás agysérülés és a PM kapcsán az utóbbi idôben megjelent egy metaanalízis (Wong Gonzalez és Buchanan, 2019), illetve egy szakirodalmi áttekintés (Raskin és mtsai, 2018) is. Mindkét kutatás az agysérülést követô PM-károsodás áttekintését célozza meg, és érdekes eredményekkel szolgál a téma tekintetében, azonban véleményünk szerint túl szúk, illetve túl tág kritériumrendszert követ. Wong Gonzalez és Buchanan (2019) metaanalízise a traumás agysérülésen belül csak a mérsékelt és a súlyos eseteket veszi be az elemzésébe, kizárva ezzel az enyhe sérüléseket. A metaanalízis további hátránya, hogy mindössze három feladatjellemzô hatását elemzi: a PM-feladat típusát, a kulcsinger kiugró jellegét és a folyamatban lévô feladat összetettségét; nem tesz azonban említést egyéb feladatjellemzókrôl, illetve az agysérült személyek klinikai és demográfiai jellemzôinek hatásáról. Ezzel szemben Raskin és munkatársainak (2018) szakirodalmi áttekintése a feladatjellemzók és klinikai jellemzók tekintetében egy sokkal átfogóbb leírást ad. Azonban ennek a kutatásnak a fókuszában egy tágabb vizsgálati minta - a szerzett agysérülés - áll, mely a traumás eseteken felül magában foglalja a stroke-ot, a daganatot, a fertôzéseket, a hipoxiát és az encephalopathiát, továbbá a tág életkori övezet miatt az idôsekkel végzett vizsgálatokat is.

E hiányosságok kiküszöbölése érdekében tanulmányunkban az alábbi szempontok alapján választottuk ki a témával foglalkozó irodalmat: 2020. április 15-ig angol nyelven publikált empirikus tanulmányok, amelyekben traumás agysérüléssel diagnosztizált felnôtt személyek PM-teljesítményét hasonlították össze a hozzájuk életkorban és iskolázottságban illesztett egészséges kontrollcsoporttal. A PM mérésére alkalmazott eszközzel kapcsolatban kritérium volt, hogy tartalmazzon esemény- vagy idôalapú feladatot, illetve a szándék megfogalmazása és végrehajtása közötti késleltetés során a résztvevôk egy folyamatban lévô feladatot végezzenek. Tanulmányunk nem tárgyalja az olyan cikkek eredményét, amelyekben a traumás agysérült csoport mellett más szerzett agyi sérüléssel (pl. stroke) rendelkezô személyek is voltak a résztvevôk között; az olyan cikkeket, ahol gyerekeket, serdülóket vagy idôs személyeket vizsgáltak; ahol nem volt megfelelốen illesztett egészséges kontrollcsoport; illetve az olyan kutatásokat, amelyekben a PM-feladat jellemzôi nem feleltek meg az elôzetesen felsorolt kritériumoknak. Az irodalomkutatás eredményeként 25 cikket találtunk a témában, 
amelyeket 1999 és 2020 között publikáltak. A továbbiakban a prospektív emlékezettel kapcsolatos kutatási eredményeket két nagyobb téma mentén foglaljuk össze: elôször áttekintjük a különbözô klinikai jellemzôk hatását, úgymint a sérülés súlyossága, lokalizációja, a kómában és PTA-ban töltött idô, a sérülés óta eltelt idô, a hangulatzavarok és premorbid kognitív zavarok; majd rátérünk az olyan feladatjellemzôk hatására, mint a mérốeszköz típusa, a PM összetevôi, illetve a prospektív kulcsinger és a folyamatban lévố feladat jellegzetességei.

\section{EREDMÉNYEK}

A sérülés súlyossága

A traumás agysérült személyek PM-teljesítményét vizsgáló empirikus cikkek többsége mérsékelt és súlyos sérülteket vizsgált: a kiválasztott 25 cikkból mindössze két kutatásban vettek részt enyhe sérüléssel jellemezhetô személyek. Ennek két lehetséges oka van: egyrészt az enyhe sérülteknél a kognitív funkciók általában hamar visszaállnak a sérülés elôtti szintre, másrészt e betegcsoport kutatásba való bevonása nehezebb a súlyos sérültekhez képest, mivel az enyhe sérülést követôen a betegek hamar elhagyják a klinikát, így rövid az az idôablak, amelyben megtörténhet a vizsgálatuk (Shum és mtsai, 2011). Az enyhe sérültekkel végzett kutatások, bár különbözó vizsgálati eljárásokat használtak, mindkét esetben csökkent PM-teljesítményt találtak a kontrollcsoporthoz képest, ráadásul ez a PM-deficit esemény- és időalapú feladatokon is megmutatkozott (Tay, Ang, Lau, Meyyappan és Collinson, 2010; Lajeunesse és mtsai, 2019). Tay és munkatársai (2010) eredményei szerint a betegcsoportban megfigyelhetô csökkent PM-múködés nemcsak a traumát követô akut idôszakban, hanem három hónappal késôbb is kimutatható volt. A mérsékelt és súlyos sérülést szenvedett személyek kognitív funkcióit vizsgáló kutatások szintén csökkent PM-teljesítményt találtak a kontrollcsoporthoz képest. A kutatások nagy részében kizárólag súlyos sérülteket vizsgáltak (Kinsella, Ong és Tucker, 2009; Knight, Titov és Crawford, 2006; Mioni, Stablum, McClintock és Cantagallo, 2012; Mioni, Rendell, Henry, Cantagallo és Stablum, 2013; Mioni, Rendell, Terrett és Stablum, 2015; Mioni és mtsai, 2017), néhány kutatásban viszont mérsékelt és súlyos sérültek együttesen alkották a kísérleti csoportot (Banville és Nolin, 2012; Clune-Ryberg és mtsai, 2011; O’Brien és Kennedy, 2018). Az empirikus kutatásokban részt vevố traumás agysérült betegek sérülésének súlyosságát az 1. táblázat tartalmazza a betegcsoport demográfiai és klinikai jellegzetességei között. Jelen tudásunk szerint nincs olyan kutatás, amelyben direkt módon hasonlították volna öszsze az enyhe, a mérsékelt és a súlyosan sérült betegcsoportok PM-teljesítményét, habár egy ilyen fókuszú kutatás a jövóben érdekes lehet, tekintve, hogy a kómában töltött idó vagy a PTA hossza fontos elôrejelzôi lehetnek a késôbbi kognitív funkcióknak (Bishara és mtsai, 1992; Brooks és mtsai, 1980; Haslam és mtsai, 1994). 


\section{A sérülés lokalizációja}

Az áttekintett 25 cikkból mindössze kilenc közölte a trauma következtében fellépô sérülés lokalizációjára vonatkozó adatokat, amit az 1. táblázatban tüntettünk fel. E kutatások nagy részében frontális lézióval jellemezhetô személyek vettek részt (Banville és Nolin, 2012; Kinch és McDonald, 2001; Mioni és mtsai, 2012, 2013, 2015, 2017; Palermo és mtsai, 2020), míg két esetben a sérülés lokalizációjának tekintetében heterogén mintát vizsgáltak (Henry, Phillips és mtsai, 2007; Maujean, Shum és McQueen, 2003). Nincs tudomásunk olyan kutatásról, amely a sérülés helyének alapján hasonlította volna össze betegek alcsoportjait, illetve olyan kutatásról sem, amelyben jobb és bal oldali sérültek PM-teljesítményét hasonlították volna össze.

\section{Kómában töltött idô, PTA hossza, sérülés óta eltelt idô}

Az elemzésbe bevont kutatások többségében a traumás agysérült csoport klinikai jellemzôi között feltüntetik a kómában töltött idôt, illetve a poszttraumás amnéziában töltött napok számát. Ezeket a változókat a kutatások leginkább a sérülés súlyosságának megállapítására használják; és mindössze öt kutatás vizsgálta meg, hogy e tudatvesztéssel jellemezhetô idôszakok hossza és a sérülés óta eltelt idô milyen együtt járást mutat a PM-teljesítménnyel. Az említett kutatások egyikében sem találtak együtt járást a PM-teljesítmény és a kómában töltött idő (Knight, Hartnett és Titov, 2005; Palermo és mtsai, 2020; Pavawalla, Schmitter-Edgecombe és Smith, 2012; Schmitter-Edgecombe és Wright, 2004) vagy a PTA hossza között (Knight és mtsai, 2005; Mioni és mtsai, 2013; Pavawalla és mtsai, 2012; Schmitter-Edgecombe és Wright, 2004). Habár fontos megjegyezni, hogy az említett kutatásokban egyes betegeknél ezen változókat nem standardizált mérôeszközökkel állapították meg, hanem a résztvevôk és hozzátartozóik utólagos beszámolói alapján. A sérülés óta eltelt idô és a PM-teljesítmény kapcsán szintén nem találtak szignifikáns együtt járást a kutatások. Azonban Banville és Nolin (2012) kutatásában traumás agysérült személyek egy hagyományos és egy VR-alapú PM-feladatban is a kontrollszemélyekhez hasonló teljesítményt nyújtottak, amit a szerzók részben azzal magyaráztak, hogy a kutatásban részt vevố személyeknél átlagosan négy év telt el a sérülés óta.

\section{Hangulatzavarok}

Traumás agysérülést követôen kialakulhatnak különbözô pszichiátriai kórképek; ezek között pedig gyakoriak az olyan hangulatzavarok, mint a depresszió vagy a generalizált szorongás (Crowe, 2008, 1). Az áttekintett kutatások kontroll alatt tartották ezeket a változókat azáltal, hogy a kísérleti csoportba csak olyan résztvevóket választottak be, akiknél nem volt kimutatható klinikailag szignifikáns hangulatzavar. A kiválasztott cikkek közül hét kutatás vizsgálta meg a hangulati állapotok és a PM-teljesítmény közötti kapcsolatot, ezeket az eredményeket a 2. táblázatban foglaltuk össze. E kutatásokban 
a szubklinikai hangulati állapotokat önjellemzô kérdőívekkel mérték fel, a kérdôívek pontszámait pedig a PM-feladatok eredményével korreláltatták. A kutatások többségében nem találtak szignifikáns együtt járást a depresszió és/vagy a szorongás szintje és a PM-teljesítmény között (Knight és mtsai, 2005; Lajeunesse és mtsai, 2019; Mathias és Mansfield, 2005; Potvin és mtsai, 2011; Tay és mtsai, 2010). Ezzel szemben Kinch és McDonald (2001) kutatásukban azt találták, hogy a szorongás mértéke elôrejelezte az eseményalapú PM-teljesítményt, míg a depresszió szintje az idôalapú PM-teljesítménnyel volt összefüggésben; a szorongás és a depresszió magasabb szintje mindkét kulcsinger esetén alacsonyabb PM-teljesítményhez vezetett. Clune-Ryberg és munkatársainak (2011) kutatása szintén arra világít rá, hogy a hangulati állapotoknak lehet bizonyos szerepe a prospektív kulcsingerek detektálásában: eredményeik szerint alacsony, de szignifikáns korreláció mutatható ki a szubklinikai depresszív szimptómák és a PM-kulcsinger detektálása között a traumás agysérült csoportban, míg kutatásukban a szorongás nem járt együtt a PM-teljesítménnyel. Ezek az eredmények illeszkednek azokhoz a korábbi kutatási eredményekhez, melyek szerint major depresszióban csökkent PM-teljesítmény figyelhetô meg (Rude és mtsai, 1999; Altgassen, Kliegel és Martin, 2009).

\section{Komorbid kognitív zavarok}

Egy jövôbeli szándék sikeres felidézéséhez és végrehajtásához számtalan kognitív funkció hozzájárulhat, melyek traumás agysérülés következtében diszfunkcionális múködést mutatnak. Az általunk vizsgált 25 empirikus cikk mindegyike felmérte a PM-teljesítményt meghatározó kognitív háttérváltozókat, ám az eredmények e tekintetben nem konzisztensek. Ezeket az eltérô eredményeket magyarázhatjuk egyrészt a számtalan különbözô neuropszichológiai teszttel, a különböző típusú PM-feladatokkal, illetve a vizsgálati minta demográfiai és klinikai jellegzetességeivel is. A kutatások során legtöbbet vizsgált változók az epizodikus emlékezet, a munkamemória, a végrehajtó funkciók, a figyelem, illetve a feldolgozás sebessége.

A PM kapcsán az epizodikus emlékezet a szándék tartalmának kódolásában és tárolásában, azaz elsôsorban a retrospektív összetevố során játszik szerepet (Carlesimo és mtsai, 2004; Kvavilashvili, 1987). Azonban az eredmények inkonzisztensek azzal kapcsolatban, hogy a traumás agysérült személyek retrospektív emlékezeti teljesítménye milyen mértékben határozza meg a PM-funkciót. Egyes kutatások nem találtak kapcsolatot traumás agysérülést követốn a retrospektív emlékezet és a PM között (Henry, Phillips és mtsai, 2007; Mathias és Mansfield, 2005; Palermo és mtsai, 2020), míg más kutatások szignifikáns összefüggést kaptak (Clune-Ryberg és mtsai, 2011; Kinch és McDonald, 2001; Knight és mtsai, 2005; Potvin és mtsai, 2011). Az eredményeket tovább árnyalja, hogy bizonyos esetekben a retrospektív emlékezeti teljesítmény a prospektív emlékezetnek csak bizonyos összetevőjével vagy típusával járt együtt. Kinch és McDonald (2001) kutatásában például csak az eseményalapú kulcsinger esetén jelezte elôre a PM-teljesítményt a retrospektív emlékezet múködése. 
Az empirikus kutatások többségében - 17 cikkben - a végrehajtó funkciók és a PM-teljesítmény összefüggéseit is megvizsgálták. Ezekben általában több teszttel igyekeztek megragadni a végrehajtó múködéseket. A 2. táblázatban részletesen feltüntettük, hogy az egyes kutatások milyen végrehajtó funkciókat mérô teszteket használtak, és jelöltük, hogy mely feladatok esetén találtak statisztikailag szignifikáns összefüggést a PM-teljesítménnyel. Ahogyan a táblázatból is látható, az eredmények ez esetben is meglehetôsen ellentmondásosak. Vannak olyan kutatások, amelyekben egyik végrehajtó funkciós teszt eredménye sem mutatott együtt járást a PM-teljesítménnyel (Mathias és Mansfield, 2005; Pavawalla és mtsai, 2012; Schmitter-Edgecombe és Wright, 2004); olyan kutatások, amelyekben a végrehajtó funkciókat méró tesztek eredményeinek csak egy része mutatott összefüggést a PM múködésével (például Canty és mtsai, 2014; Mioni és mtsai, 2013; Palermo és mtsai, 2020); továbbá olyan kutatások is, amelyekben csupán az összevont végrehajtó komponens változója mutatott összefüggést a PM-mel (Kinch és McDonald, 2001; Lajeunesse és mtsai, 2019).

Az áttekintett irodalom alapján a végrehajtó funkciókat mérô tesztek közül kiemelkednek a kognitív rugalmasságot mérô fluenciatesztek. Fonemikus és kategóriafluencia-teszteket ugyanis szinte az összes olyan kutatásban alkalmaztak, amelyekben a végrehajtó funkciók és a PM kapcsolatára keresték a választ, és a kutatások nagy részében a traumás agysérült személyek fluenciateljesítménye kapcsolatban állt PM-teljesítményükkel (Canty és mtsai, 2014; Clune-Ryberg és mtsai, 2011; Knight és mtsai, 2005; Maujean és mtsai, 2003; Mioni és mtsai, 2013; Palermo és mtsai, 2020; Potvin és mtsai, 2011). A fluenciatesztek mellett kiemelkedik még a gátlási funkciókat méró Stroop-feladat, melynek eredménye szintén több kutatásban mutatott szignifikáns öszszefüggést traumás agysérült személyek PM-teljesítményével (Clune-Ryberg és mtsai, 2011; Potvin és mtsai, 2011; Raskin, Shum, Ellis, Pereira és Mills, 2017).

A retrospektív emlékezethez hasonlóan ugyanakkor a végrehajtó funkciók is összetett kapcsolatban állnak a PM-mel. Erre utalnak azok az eredmények, melyek szerint a végrehajtó tesztek eredményei a PM-nek csak egyes összetevôivel vagy csak bizonyos kulcsingerek esetén mutatnak együtt járást. Potvin és munkatársai (2011) kutatásában például a kategória fluencia eredménye traumás agysérült személyeknél csak a PM retrospektív komponensével mutatott szignifikáns korrelációt, míg a Stroop-teszt eredménye csak a prospektív komponenssel járt együtt. Mioni és munkatársai (2013) kutatásában pedig a traumás agysérült csoport kategóriafluencia-teljesítménye csak az idôalapú PM-feladat eredményével járt együtt. Maujean és munkatársai (2003) kutatásában továbbá a fonemikus fluencia eredménye csak a magas kognitív terhelésú folyamatban lévô feladat esetén járt együtt a PM-teljesítménnyel.

\section{A PM-méróeszköz típusa}

Az eddigi irodalom alapján megállapítható, hogy traumás agysérült személyeknél gyakori és tartós a PM-deficit, és ez egy olyan robusztus jelenség, melyet számos különbözô méróeszköz igazolt (Wong Gonzalez és Buchanan, 2019). A bevezetőben tárgyalt különbözô PM-feladatok közül traumás agysérült betegeket vizsgáltak már klasszikus laboratóriumi kísérletekkel (Henry, Phillips és mtsai, 2007), videó- és VR-alapú eszkö- 
zökkel (Banville és Nolin, 2012; Knight és mtsai, 2005), standardizált klinikai tesztekkel (Tay és mtsai, 2010) és klinikai orientációjú laboratóriumi feladatokkal (Mioni és mtsai, 2013), egyes kutatások pedig naturalisztikus feladatokkal és önjellemzô kérdőivekkel is kiegészítették a vizsgálatokat (O’Brien és Kennedy, 2018; Potvin és mtsai, 2011). Raskin és munkatársai (2017) kutatása kifejezetten arra vállalkozott, hogy a különbözô PM-mérôeszközökön nyújtott teljesítményt vizsgálja meg ebben a betegpopulációban. Eredményeik szerint traumás agysérült személyek PM-teljesítménye egy standardizált klinikai teszten és egy laboratóriumi feladatban is alacsonyabb volt, mint az egészséges kontrollcsoporté, továbbá az önjellemzô kérdőív eredményei alapján a betegek a mindennapi élethez kapcsolódó tevékenységekkel kapcsolatban is alacsonyabb PM-teljesítményrôl számoltak be.

Találhatunk azonban néhány olyan kutatást is, amelyekben bizonyos feladatokban a traumás agysérült személyek PM-teljesítménye nem maradt el az egészséges személyekétôl. Palermo és munkatársai (2020) kutatásában a MIST-teszt laboratóriumban végzett részén a betegek sérült PM-múködést mutattak, viszont az egynapos késleltetést követô, otthonról elvégzendó időalapú PM-feladatban a kontrollszemélyekéhez hasonló teljesítményt mutattak. Banville és Nolin (2012) kutatása szintén arra világít rá, hogy bizonyos kísérleti helyzetekben traumás agysérült személyek PM-teljesítménye nem tér el szignifikánsan az egészséges személyekétôl. Eredményeik szerint a mérsékelt és súlyos, többségében frontális sérüléssel jellemezhető személyek normális PM-teljesítményt mutattak egy hagyományos klinikai teszten (Rivermead Viselkedéses Memóriateszt), illetve egy VR-alapú PM-feladaton is. Az áttekintett kutatásokban alkalmazott PM-mérôeszközök típusát a 2. táblázatban foglaltuk össze.

\section{Idôalapú és eseményalapú feladatok}

A traumás agysérült személyek PM-teljesítményére nagy hatással van a prospektív kulcsinger típusa. Az áttekintett kutatásokból egy (Mioni és mtsai, 2012) vizsgálta meg a traumás agysérülés hatását kizárólag az időalapú PM esetén, kilenc kutatás eseményalapú PM-et vizsgált, míg tizenöt kutatásban mindkét típusú kulcsingert használták (lásd 2. táblázat). Az egyik legkorábbi kutatás során Shum, Valentine és Cutmore (1999) az idô- és eseményalapú feladatok mellett a cselekvésalapú PM-teljesítményt is vizsgálták. Eredményeik szerint traumás agysérülést szenvedett személyek mindhárom feladattípusban alacsonyabb PM-teljesítményt nyújtottak, mint az egészséges kontrollcsoport; a teljesítményük a cselekvésalapú feladatokban volt a legmagasabb, míg az idôalapú feladatokban a legalacsonyabb. Azokban a kutatásokban, amelyekben időalapú és eseményalapú PM-feladatokat is használtak, a traumás agysérült személyek gyengébb teljesítményt mutattak az idôalapú feladatokban az eseményalapú feladatokhoz képest (Canty és mtsai, 2014; Mioni és mtsai, 2013; Palermo és mtsai, 2020; Raskin és mtsai, 2017). A többszörös folyamatok elmélete (McDaniel és Einstein, 2000) szerint az idôalapú feladatok stratégiai monitorozást és ezáltal nagyobb kognitív erôforrást igényelnek, mivel az ilyen feladatok végrehajtásához önindította cselekvésre van szükség, és a prospektív kulcsinger és a szándék tartalma közötti kapcsolat önkényes. 
Nem elhanyagolható tényezó azonban az időalapú feladatoknál a késleltetés mértéke, amelyet több kutatásban is megvizsgáltak. Egyes kutatásokban az egyik népszerú klinikai mérốeszközzel, a MIST-teszttel kapott eredmények alapján a traumás agysérült betegek csak a hosszabb (15 perces) késleltetés esetén mutattak alacsonyabb PM-teljesítményt az egészséges személyekhez képest, míg a rövid (2 perces) késleltetés esetén nem (Raskin és mtsai, 2017; Tay és mtsai, 2010). Ennek azonban ellentmondanak azok a kutatások, amelyekben rövidebb és hosszabb késleltetés mellett is sérült PM-teljesítmény volt megfigyelhetô traumás agysérült személyeknél (Mathias és Mansfield, 2005; Palermo és mtsai, 2020).

\section{Prospektiv és retrospektív összetevók}

Az áttekintésbe bevont tanulmányok közül 17 kutatás vizsgálta meg azt, hogy a traumás agysérült személyek a szándék megfelelő idôben vagy helyzetben történô végrehajtásában (prospektív összetevô) mutatnak zavart, vagy a szándék tartalmának felidézése (retrospektív összetevô) okoz nekik problémát, esetleg a két összetevô együttesen sérül. Az eredményeket a 2. táblázatban foglaltuk össze. A kutatások egy részében olyan globális sérülést találtak, amelyben a prospektív és a retrospektív összetevô egyaránt érintett volt traumás agysérülést követôen (például Carlesimo, Formisano, Bivona, Barba és Caltagirone, 2010; Palermo és mtsai, 2020; Raskin és mtsai, 2017). Ezzel szemben bizonyos kutatások eredménye szerint traumás agysérült személyek csak a prospektív összetevô esetén mutattak csökkent PM-teljesítményt (Canty és mtsai, 2014; Clune-Ryberg és mtsai, 2011; Henry, Phillips és mtsai, 2007; Kinsella és mtsai, 2009; Shum és mtsai, 1999; Tay és mtsai, 2010). Olyan kutatást azonban nem találtunk az irodalomban, amelyben traumás agysérülést követôen a betegek PM-teljesítményét a prospektív összetevô épsége mellett a retrospektív összetevô sérülése határozta meg - habár O’Brien és Kennedy (2018) kutatásában a két PM-összetevô közül a retrospektív sérülése hangsúlyosabb volt. Ez utóbbi kutatás további érdekes eredménye, hogy amikor az agysérült személyeknek előzetesen meg kellett becsülniük a teljesítményüket a PM-feladatban, akkor csak a retrospektív összetevô felidézésének sikerét becsülték túl, míg a prospektív összetevô esetén nem volt különbség a becsült és a valós teljesítmény között.

Fontos kiemelni, hogy a prospektív és retrospektív összetevôk sérülése egy összetett folyamat, melyet számos tényezô befolyásolhat, úgymint a prospektív kulcsinger típusa vagy az egyes kognitív háttérváltozók. Potvin és munkatársai (2011) kutatásukban szignifikáns interakciót találtak az összetevôk és a kondíció között a traumás agysérült csoportban: a prospektív és a retrospektív összetevô is az időalapú kulcsinger esetén sérült kifejezettebben, szemben az eseményalapú kulcsingerrel. Tovább árnyalja a képet Lajeunesse és munkatársainak (2019) kutatása, melynek eredményei szerint enyhe traumás agysérülés esetén a prospektív összetevô csak az időalapú feladatoknál mutatott sérülést, míg a retrospektív összetevô sérülése megállapítható volt idô- és eseményalapú feladatoknál is. Az egyes összetevôk sérülésére a kulcsinger gyakorisága is hatással lehet: Mioni és munkatársainak (2017) eredményei szerint a retrospektív összetevô csak az epizodikus és idôalapú feladatok esetén mutatott sérülést az egész- 
séges személyekhez képest, míg szokásalapú és eseményalapú feladatoknál nem; ezzel szemben a prospektív összetevô minden feladattípus esetén sérülést mutatott. A kognitív háttérváltozók tekintetében úgy tûnik, hogy a retrospektív összetevô az epizodikus emlékezeti teljesítménnyel jár együtt (Carlesimo és mtsai, 2004; Carlesimo és mtsai, 2010; Potvin és mtsai, 2011), míg a prospektív összetevô a figyelemmel és a végrehajtó funkciókkal (Potvin és mtsai, 2011). Ám ezeket az együtt járásokat is befolyásolhatja a PM-feladat típusa: Kinch és McDonald (2001) eredményei szerint időalapú feladatoknál a prospektív és a retrospektív összetevốt is a végrehajtó funkciók jósolták be, eseményalapú feladatoknál a prospektív összetevô az epizodikus emlékezettel és a végrehajtó funkciókkal járt együtt, míg a retrospektív összetevő semmilyen háttérváltozóval nem mutatott együtt járást.

\section{A kulcsinger kiugró jellege és a folyamatban lévô feladat}

A többszörös folyamatok elmélete alapján a kiugró jellegú kulcsingerek könnyen ragadják meg a figyelmet, és váltanak ki automatikus elóhívási folyamatokat, ezáltal pedig segítik a PM-teljesítményt; míg a kevésbé kiugró ingerek detektálása több végrehajtó és figyelmi múködést igényel (McDaniel és Einstein, 2000). Emellett a fenntartott figyelmet, folyamatos és összetett válaszadást igénylő folyamatban lévô feladatok több kognitív erôforrást igényelnek, és ezáltal megnehezítik azt, hogy egy személy egyidejúleg a PM-feladattal is foglalkozzon, míg egy egyszerúbb feladat során több erôforrása maradhat a prospektív kulcsingerek detektálására.

Wong Gonzalez és Buchanan (2019) metaanalízisének eredményei alapján traumás agysérült személyek PM-teljesítményére szignifikáns hatással volt mind a kulcsinger kiugró jellege, mind a folyamatban lévố feladat összetettsége. Az általunk áttekintett tanulmányok eredményeibôl is erre következtethetünk. Maujean és munkatársai (2003) szerint traumás agysérülést követôen csak a magas kognitív terhelésú folyamatban lévô feladat esetén teljesítettek rosszabbul a betegek egy eseményalapú PM-feladatban a kontrollcsoporthoz képest, míg az alacsony kognitív terhelésú feladatban nem mutatkozott különbség a két csoport között. Továbbá azokban a kutatásokban, ahol nem találtak különbséget az agysérült és az egészséges személyek PM-teljesítménye között, egyszerú folyamatban lévô feladatot használtak: Banville és Nolin (2012) például azzal magyarázták a traumás agysérült csoport normál PM-teljesítményét, hogy a kutatásukban használt VR-feladat túl könnyú volt.

\section{ÖSSZEFOGLALÁS ÉS KITEKINTÉS A REHABILITÁCIÓRA}

Szakirodalmi áttekintô tanulmányunk arra vállalkozott, hogy bemutassa a PM legfontosabb fogalmait, elméleteit, leírjon egy olyan neurológiai kórképet, amely többek között e kognitív funkció sérülésével jár együtt, illetve egy adott szempontrendszer mentén áttekintse a témával kapcsolatos empirikus irodalmat. Mint láthattuk, a PM egy olyan összetett kognitív képesség, amely elengedhetetlen a mindennapi feladataink elvégzéséhez és az önálló életvitel gyakorlásához. Egészséges funkcioná- 


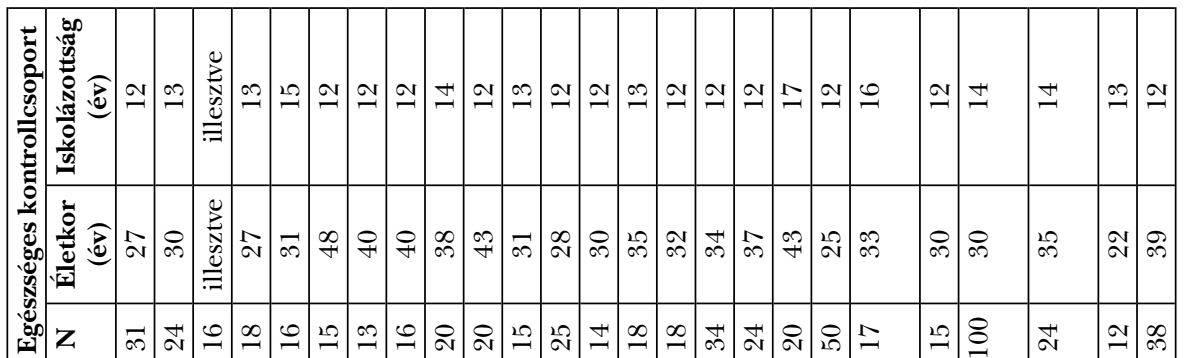

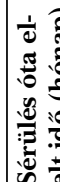

ये 艄: 㻤

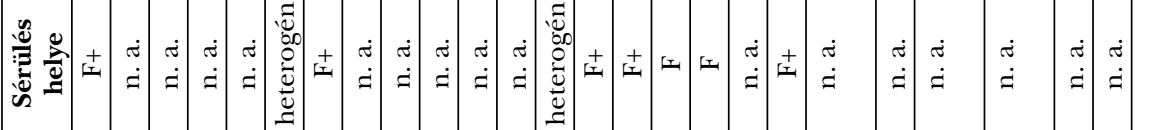
(1)

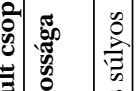

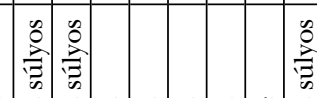

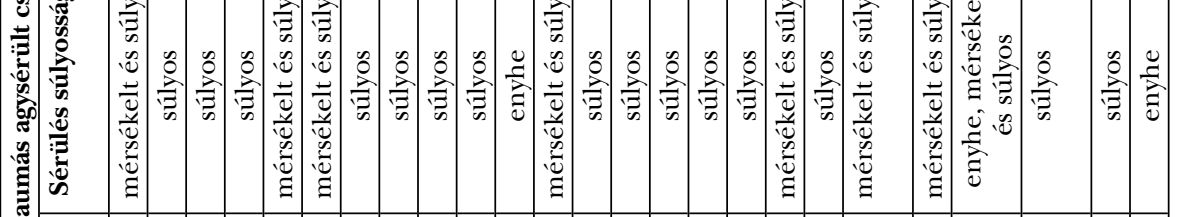
H.

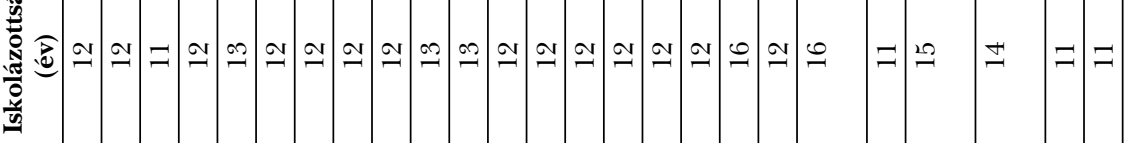

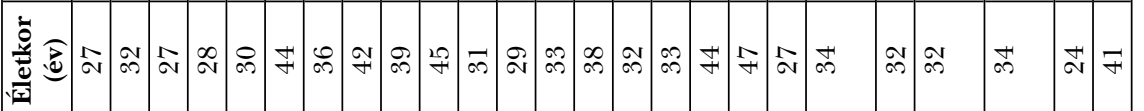

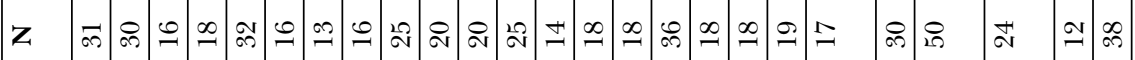

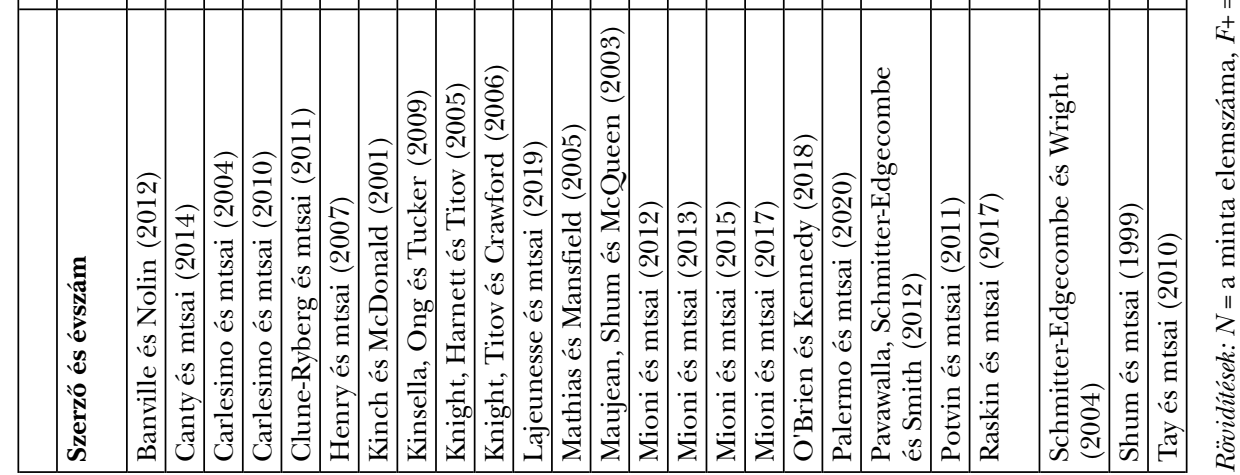




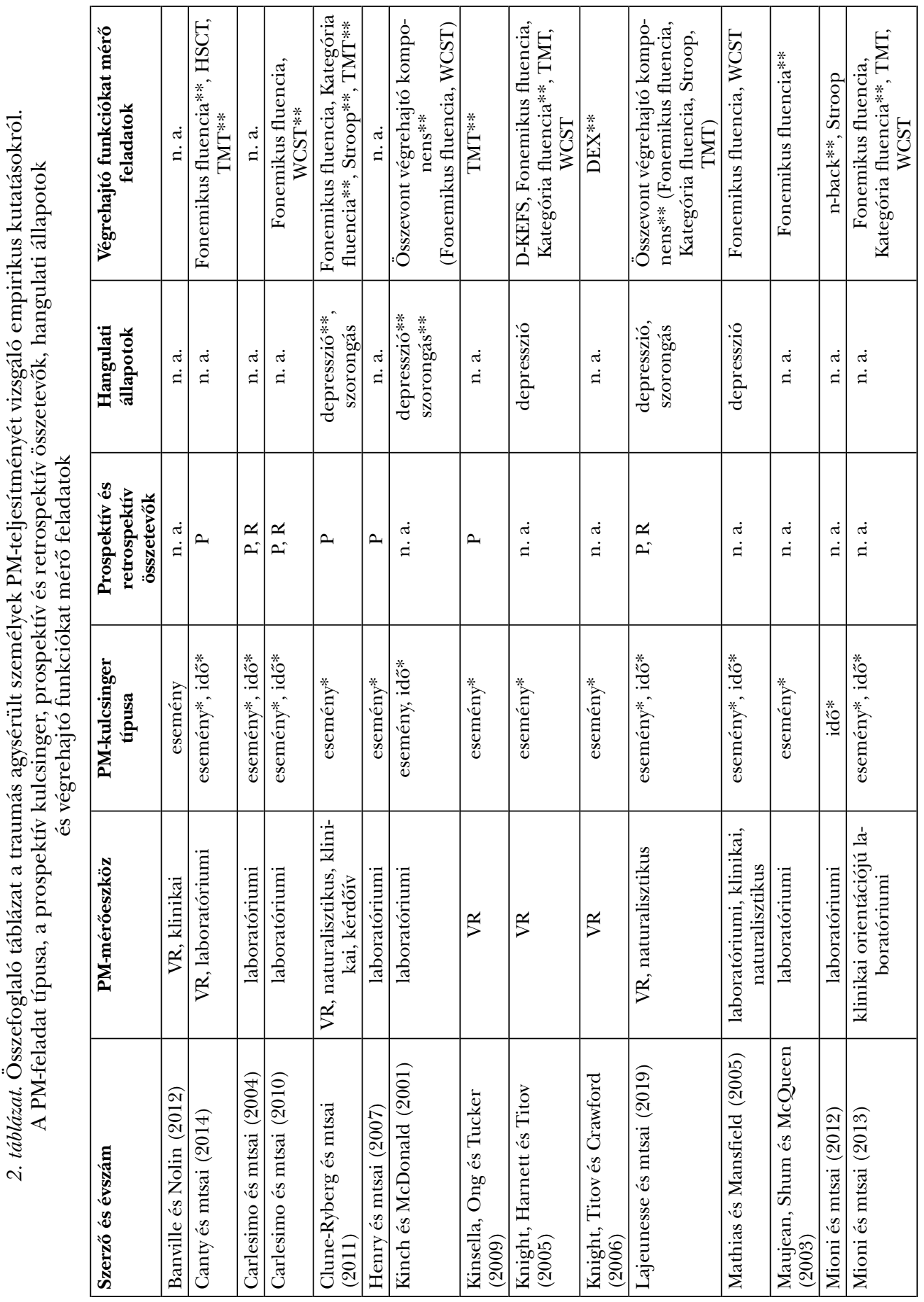




\begin{tabular}{|c|c|c|c|c|c|c|c|c|c|c|c|}
\hline 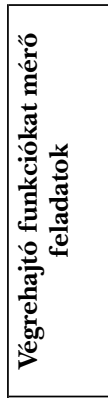 & $\mid \begin{array}{l}\dot{0} \\
\dot{a}\end{array}$ & $\begin{array}{l}\dot{\sim} \\
\dot{\Omega}\end{array}$ & $\begin{array}{l}\dot{\delta} \\
\dot{=}\end{array}$ & 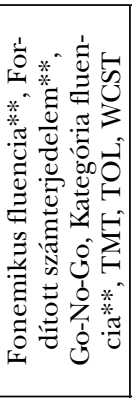 & 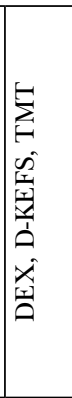 & 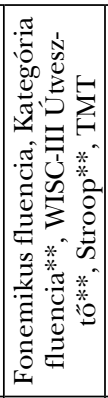 & \begin{tabular}{l}
$*$ \\
\multirow{2}{*}{} \\
8 \\
0 \\
0 \\
0 \\
0
\end{tabular} & 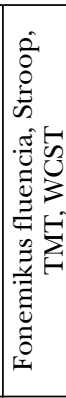 & $\begin{array}{l}\stackrel{\sim}{a} \\
\dot{g}\end{array}$ & $\begin{array}{l}\stackrel{\sim}{\circ} \\
\stackrel{2}{2}\end{array}$ & 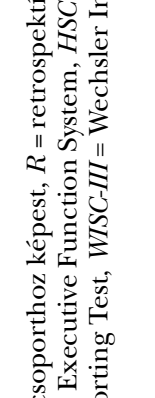 \\
\hline 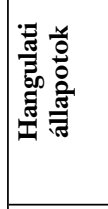 & $\begin{array}{l}\dot{\theta} \\
\dot{a}\end{array}$ & $\begin{array}{l}\stackrel{\leftrightarrow}{a} \\
\dot{a}\end{array}$ & $\mid \begin{array}{l}\dot{x} \\
\dot{=}\end{array}$ & $\begin{array}{l}\stackrel{\sim}{a} \\
\dot{a}\end{array}$ & 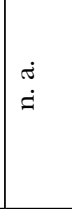 & 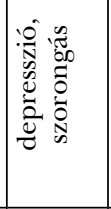 & 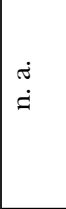 & $\begin{array}{l}\dot{\Im} \\
\dot{a}\end{array}$ & 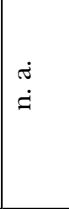 & 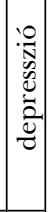 & 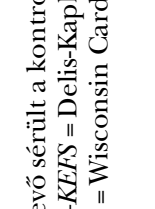 \\
\hline 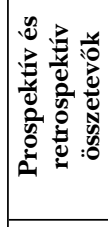 & $\approx$ & $\stackrel{x}{2}$ & $\begin{array}{l}\simeq \\
\therefore \\
\therefore i\end{array}$ & $\begin{array}{l}\simeq \\
=\end{array}$ & $\frac{1}{2}$ & 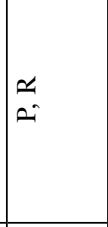 & $\frac{x}{2}$ & $\begin{array}{l}\dot{\sim} \\
\dot{a}\end{array}$ & a & $\theta$ & 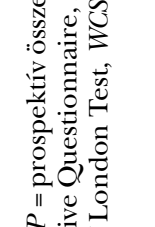 \\
\hline 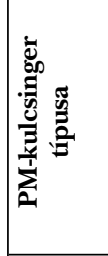 & 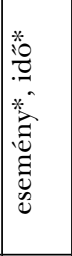 & 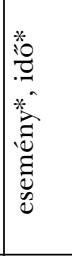 & 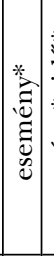 & 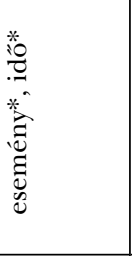 & 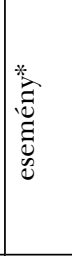 & 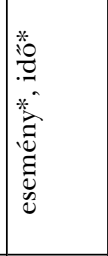 & 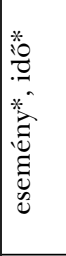 & 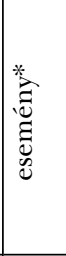 & 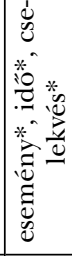 & 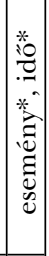 & 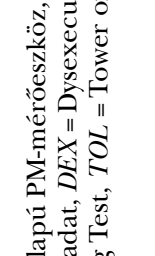 \\
\hline 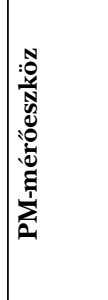 & 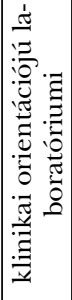 & 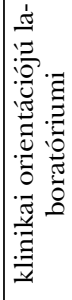 & 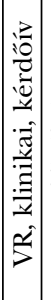 & 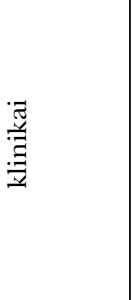 & 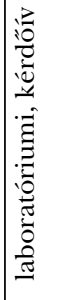 & 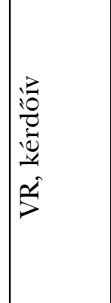 & 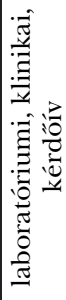 & 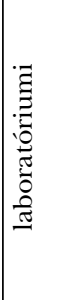 & 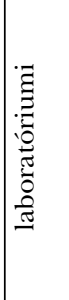 & 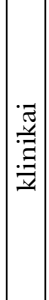 & 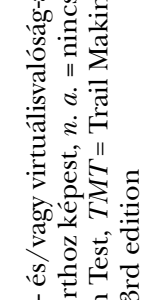 \\
\hline 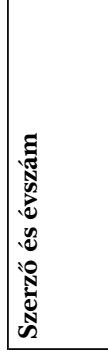 & 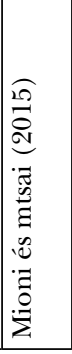 & 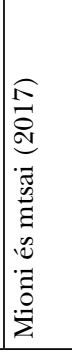 & 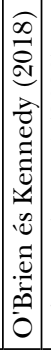 & 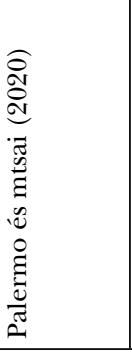 & 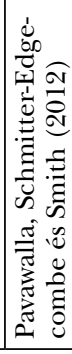 & 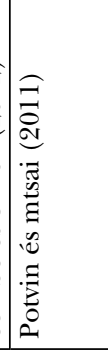 & 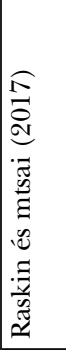 & 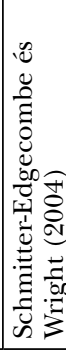 & 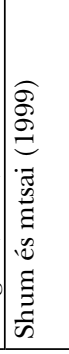 & 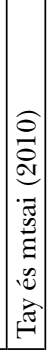 & 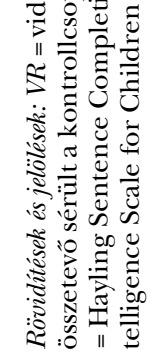 \\
\hline
\end{tabular}


lása elsôsorban egy jól körülírt agyi struktúrához, a rostrális prefrontális kéreghez köthetô (Burgess és mtsai, 2001; Okuda és mtsai, 2007). A PM múködésében zavarok keletkezhetnek, amennyiben ez az agyterület, illetve a vele kapcsolatban álló agyi régiók sérülést szenvednek. Számos kutatás rávilágított arra, hogy különbözô eredetû neurológiai kórképek esetén jellemzô a PM-diszfunkció (Kliegel és mtsai, 2012). A traumás agysérülés egy gyakori neurológiai kórkép, melynek következményeként gyakran szenvednek fokális sérülést a prospektív emlékezethez elengedhetetlen neurális struktúrák (Levin és Krauss, 1994). Az elmúlt két évtized kutatásai arra világították rá, hogy ebben a populációban a figyelmi, emlékezeti és végrehajtó diszfunkciók mellett a PM zavara is jellemzô lehet (Raskin és mtsai, 2018; Wong Gonzalez és Buchanan, 2019).

A témához kapcsolódó empirikus irodalom felkutatása során 25 tanulmány eredményeit választottuk be áttekintésünkbe. A kiválasztott kutatások jelentôs hányadában azt találták, hogy a traumás agysérült személyek PM-teljesítménye szignifikáns mértékben elmarad az egészséges populációtól. Az eredmények azonban rávilágítanak arra, hogy számtalan tényezó befolyásolhatja a PM-teljesítményt: a feladat egyes jellemzói mellett a klinikai és a személyi tényezôk is meghatározók lehetnek.

Az 1999 és 2020 között megvalósult kutatások két szempontból is heterogénnek tekinthetôk. Egyrészt, a vizsgálati minta klinikai jellemzôi, úgymint a sérülés súlyossága, lokalizációja, illetve a sérülés óta eltelt idô nagy eltérést mutatnak az egyes kutatások között. Tekintve, hogy a traumás agysérüléssel diagnosztizált személyek egy igen heterogén csoportot alkotnak, ez az eredmény nem meglepô. Fontos azonban hangsúlyozni, hogy ez idáig kevés kutatás foglalkozott azzal, hogy bizonyos klinikai jellemzőknek milyen hatása van a PM-teljesítményre. Hiányoznak az irodalomból az olyan kutatások, amelyek azt vizsgálják meg, hogy milyen különbség mutatkozik enyhe, közepes és súlyos sérüléssel jellemezhetô személyek emlékezeti teljesítményében; és azzal kapcsolatban sem végeztek még kutatást, hogy miként befolyásolja a szándékokra való emlékezést a sérülés lokalizációja, lateralizációja, illetve a kómában és PTA-ban töltött idô. A jövôbeli kutatásoknak fontos lenne megvizsgálni e tényezôk hatását is, hiszen lehetôvé tehetnék a szakemberek számára, hogy a sérülésnek már az akut fázisában megbecsülhessék a hosszú távú kognitív következményeket. Továbbá javasoljuk, hogy a jövôbeli kutatások enyhe sérüléssel jellemezhetô agysérült betegeket is vizsgáljanak. Áttekintésünkben mindössze két olyan kutatást találtunk, melyek enyhe sérültek PM-funkcióit vizsgálták: mindkettô sérült PM-múködést talált a kontrollcsoporthoz képest. Tay és munkatársai (2010) eredményei arra is rávilágítottak, hogy a csökkent PM-funkciók nemcsak az akut idôszakban, hanem a sérülés után három hónappal is fennálltak. Ezek az eredmények ellentmondanak korábbi kutatásoknak, amelyek szerint az enyhe sérülést követôen a kognitív funkciók hamar visszaállnak a premorbid szintre (Iverson, 2005; Schretlen és Shapiro, 2003).

Az áttekintett kutatások abból a szempontból is heterogénnek tekinthetôk, hogy milyen mérốeszközt használtak a PM-funkciók felmérésére, és a PM-feladat mely jellemzőire fókuszáltak az eredmények értelmezése során. A PM-feladat típusának nem volt meghatározó szerepe: traumás agysérült személyek alacsonyabb PM-teljesítményt mutattak az egészséges személyekhez képest különbözô laboratóriumi, naturalisztikus és klinikai méróeszközökön is. A feladat kapcsán a PM-teljesítményt leginkább a 
prospektív kulcsinger típusa és kiugró jellege, illetve a folyamatban lévô feladat öszszetettsége befolyásolja. Az áttekintett kutatások alapján megállapítható, hogy az idôalapú, nem kiugró kulcsingerek és a komplex folyamatban lévô feladatok esetén a legnagyobb a különbség a traumás agysérült és az egészséges személyek teljesítménye között. Ez feltehetőleg azzal magyarázható, hogy az ilyen feladatok nagymértékú monitorozást, önindította tervezést és kognitív erôforrást igényelnek (Wong Gonzalez és Buchanan, 2019). E tényezôk magyarázhatják továbbá a végrehajtó funkciók és a PM közötti komplex kapcsolatot is. Az áttekintett kutatások szerint ugyanis traumás agysérült személyeknél a végrehajtó funkciókat mérô tesztek eredménye csak akkor járt együtt a PM-teljesítménnyel, ha magas kognitív terhelésú feladatot alkalmaztak (Maujean és mtsai, 2003), vagy ha idôalapú kulcsingert használtak (Mioni és mtsai, 2013). Ez összhangban van azokkal az eredményekkel is, melyek szerint a végrehajtó funkciók hozzájárulása a PM múködéséhez nagymértékben függ attól, hogy milyen PM-feladatot használunk (Martin és mtsai, 2003). Ugyanakkor nemcsak a PM-, hanem a végrehajtó funkciók mérésére használt feladatoknak is szerepe lehet a két tényezó kapcsolatában. A kognitív rugalmasság és a gátlási folyamatok fontosságára hívja fel a figyelmet az az eredmény, miszerint a betegcsoportban leginkább a verbális fluenciatesztek és a Stroop-feladat eredményei álltak kapcsolatban a PM-teljesítménnyel (pl. Clune-Ryberg és mtsai, 2011; Palermo és mtsai, 2020). Az eredményeket azonban tovább árnyalja, hogy több olyan kutatást is azonosítottunk, amelyben a végrehajtó múködések nem álltak kapcsolatban traumás agysérült személyek PM-teljesítményével (Mathias és Mansfield, 2005; Pavawalla és mtsai, 2012; Schmitter-Edgecombe és Wright, 2004). Ezek a kutatások nem közöltek pontos adatokat a sérülés lokalizációjával kapcsolatban, így nem tudhatjuk, hogy a vizsgált betegeknél milyen mértékben volt érintett a prefrontális kéreg, amely mindkét kognitív funkció múködéséhez elengedhetetlen. A jövôbeli kutatásoknak a sérülés lokalizációjának pontos feltüntetése mellett érdemes lenne tovább vizsgálnia a két kognitív funkció kapcsolatát.

Szintén ellentmondásos eredményeket találtunk az idôalapú PM-feladatokban a késleltetéssel kapcsolatban, ami arra utal, hogy a késleltetés hossza nem feltétlenül járul hozzá a csoportok közötti különbséghez; e tényezó meghatározásához azonban további kutatások szükségesek. A prospektív és retrospektív összetevôk kapcsán szintén inkonzisztensek az eredmények; további vizsgálatok szükségesek annak megállapításához, hogy ebben a betegcsoportban milyen tényezók befolyásolják ezeknek a PM-összetevôknek a szelektív sérülését.

A traumás agysérült személyek PM-funkcióját meghatározó háttérváltozók nemcsak a tudományos kutatás szempontjából érdekesek, hanem kulcsfontosságúak a neuropszichológiai rehabilitáció során is; a hatékony rehabilitációs technikák kidolgozásához ugyanis fontos azonosítani azokat a tényezôket, amelyek mérsékelhetik a PM-sérülést ebben a populációban. Az elméleti áttekintésben említettük, hogy a traumás agysérülés eddigi irodalma a retrospektív emlékezeti károsodásra fókuszált, így nem meglepő, hogy rehabilitációs technikákat is inkább ezen a téren fejlesztettek ki, és mindeddig kevés kutatás foglalkozott a PM-tréning hatásaival (Fleming, Shum, Strong és Lightbody, 2005). Fontos azonban megjegyezni, hogy az emlékezet rehabilitációja nem a sérülés elootti szintre való visszaállást célozza meg; a hangsúly inkább azon van, hogy a betegnek segítsünk megérteni és kezelni a mindennapi életben felmerüló 
emlékezeti problémáit azáltal, hogy különbözô, egyénre szabott technikákat tanítunk neki (Wilson, 2004).

Az a kutatási eredmény, miszerint traumás agysérült személyeknél nagyobb PM-zavart találtak az időalapú feladatok során az eseményalapú feladatokhoz képest, könynyen felhasználható egy emlékezeti tréning során. Ha egy személynek a mindennapjai során nehézséget okoz az, hogy a gyógyszereit egy bizonyos idóben vagy bizonyos idôközönként bevegye, akkor ezt az időalapú feladatot át lehet keretezni a számára úgy, hogy egy esemény váltsa ki a szándék eloohívását, például a gyógyszer bevételét inkább az étkezésekhez, és ne konkrét idôpontokhoz kösse (Henry, Phillips és mtsai, 2007). Szintén segíti a rehabilitációt, ha elôzetesen felmérjük, hogy a betegnek a PM kapcsán a prospektív vagy a retrospektív összetevô okoz gondot. A prospektív összetevô fejlesztésében és a külsố ösztönzések internalizálódásában segíthetnek például a kompenzációs stratégia részét képzó külsô emlékeztetók, úgymint a naplók, jegyzetfüzetek, és az olyan elektronikus eszközök, mint a csipogók, okostelefon-alkalmazások vagy weboldalak (Raskin és mtsai, 2018). A belsố kompenzációs stratégiák, például a vizualizációs technika, a kezdôbetû mnemonika vagy az elaboratív kódolás szintén népszerúek a rehabilitációban, és alkalmasak mind a prospektív, mind a retrospektív összetevô fejlesztésére. A komorbid kognitív zavarok feltérképezése szintén nagy fontossággal bír. Amennyiben a neuropszichológiai tesztelés során fény derül arra, hogy egy betegnek súlyos figyelmi vagy végrehajtó funkciós problémái vannak, célszerú elôször ezeket a képességeket tréningezni, mielôtt egy összetettebb, prospektív emlékezetet fejlesztô tréninget kezdenénk el. Emellett egy PM-tréning megtervezésénél hangsúlyoznunk kell az egyénre szabott terápia fontosságát. Ahogy az áttekintett irodalomból is látszik, számtalan tényezô járulhat hozzá traumás agysérülés esetén a PM-teljesítményhez. Tanulmányunk e tényezôk közül a különbözô klinikai változókat (a sérülés súlyossága, lokalizációja, a kóma és a PTA hossza, a sérülés óta eltelt idô, komorbid hangulatzavarok), illetve a PM-feladat különbözô jellemzôit (méróeszköz jellege, prospektív kulcsinger típusa, folyamatban lévô feladat összetettsége, prospektív és retrospektív összetevôk) helyezte fókuszba. Azonban az általunk áttekintetteken felül számos más tényezô is hozzájárulhat a sikeres PM-múködéshez, úgymint a résztvevô motivációja (Jeong és Cranney, 2009), a kulcsinger valenciája (Clark-Foos, Brewer, Marsh, Meeks és Cook, 2009), a metaemlékezet (McDonald-Miszczak, Gould és Tychynski, 1999) vagy az alvásminôség (Rehel és mtsai, 2019). Javasoljuk, hogy a jövóbeli kutatások ezeket a háttérváltozókat is vegyék figyelembe traumás agysérült betegek PM-teljesítményének felmérése, értékelése során, amire az elkövetkezôkben saját empirikus kutatásainkban is kísérletet teszünk.

\section{KÖSZÖNETNYILVÁNÍTÁS}

Az Innovációs és Technológiai Minisztérium ÚNKP-19-3 kódszámú Új Nemzeti Kiválóság Programjának szakmai támogatásával készült.

Köszönjük Mikula Bernadett PhD-hallgatónak a kézirat átolvasása során nyújtott szakmai észrevételeit. 


\section{IRODALOM}

A * a szakirodalmi áttekintésbe bevont empirikus tanulmányokat jelöli.

Altgassen, M., Kliegel, M., \& Martin, M. (2009). Event-based prospective memory in depression: The impact of cue focality. Cognition and Emotion, 23(6), 1041-1055.

Altgassen, M., Williams, T. I., Bölte, S., \& Kliegel, M. (2009). Time-based prospective memory in children with autism spectrum disorder. Brain Impairment, 10(1), 52-58.

*Banville, F., \& Nolin, P. (2012). Using virtual reality to assess prospective memory and executive functions after traumatic brain injury. Journal of CyberTherapy and Rehabilitation, 5(1), $45-55$.

Bishara, S. N., Partridge, F. M., Godfrey, H. P., \& Knight, R. G. (1992). Post-traumatic amnesia and Glasgow Coma Scale related to outcome in survivors in a consecutive series of patients with severe closed-head injury. Brain Injury, 6(4), 373-380.

Bravin, J. H., Kinsella, G. J., Ong, B., \& Vowels, L. (2000). A study of performance of delayed intentions in multiple sclerosis. Journal of Clinical and Experimental Neuropsychology, 22(3), $418-429$.

Brooks, D. N., Aughton, M. E., Bond, M. R., Jones, P., \& Rizvi, S. (1980). Cognitive sequelae in relationship to early indices of severity of brain damage after severe blunt head injury. Journal of Neurology, Neurosurgery \& Psychiatry, 43(6), 529-534.

Burgess, P. W. (1997). Theory and methodology in executive function research. In Rabbit, P. (Ed), Methodology of frontal and executive function (pp. 81-116). Hove: Psychology Press.

Burgess, P. W., Quayle, A., \& Frith, C. D. (2001). Brain regions involved in prospective memory as determined by positron emission tomography. Neuropsychologia, 39(6), 545-555.

Burgess, P. W., Dumontheil, I., \& Gilbert, S. J. (2007). The gateway hypothesis of rostral prefrontal cortex (area 10) function. Trends in Cognitive Sciences, 11(7), 290-298.

Burgess, P. W., Gonen-Yaacovi, G., \& Volle, E. (2011). Functional neuroimaging studies of prospective memory: what have we learnt so far? Neuropsychologia, 49(8), 2246-2257.

*Canty, A. L., Fleming, J., Patterson, F., Green, H. J., Man, D., \& Shum, D. H. (2014). Evaluation of a virtual reality prospective memory task for use with individuals with severe traumatic brain injury. Neuropsychological Rehabilitation, 24(2), 238-265.

*Carlesimo, G. A., Casadio, P., \& Caltagirone, C. (2004). Prospective and retrospective components in the memory for actions to be performed in patients with severe closed-head injury. Journal of the International Neuropsychological Society, 10(5), 679-688.

*Carlesimo, G. A., Formisano, R., Bivona, U., Barba, L., \& Caltagirone, C. (2010). Prospective memory in patients with severe closed-head injury: Role of concurrent activity and encoding instructions. Behavioural Neurology, 22(3-4), 101-110.

Chau, L. T., Lee, J. B., Fleming, J., Roche, N., \& Shum, D. (2007). Reliability and normative data for the Comprehensive Assessment of Prospective Memory (CAPM). Neuropsychological Rehabilitation, 17(6), 707-722.

Chen, N. Y. C., \& Batchelor, J. (2019). Length of post-traumatic amnesia and its prediction of neuropsychological outcome following severe to extremely severe traumatic brain injury in a litigating sample. Brain Injury, 33(8), 1087-1096.

Clark-Foos, A., Brewer, G. A., Marsh, R. L., Meeks, J. T., \& Cook, G. I. (2009). The valence of event-based prospective memory cues or the context in which they occur affects their detection. The American Journal of Psychology, 122(1), 89-97.

*Clune-Ryberg, M., Blanco-Campal, A., Carton, S., Pender, N., O'Brien, D., Phillips, J., et al (2011). The contribution of retrospective memory, attention and executive functions to the 
prospective and retrospective components of prospective memory following TBI. Brain Injury, 25(9), 819-831.

Cona, G., Scarpazza, C., Sartori, G., Moscovitch, M., \& Bisiacchi, P. S. (2015). Neural bases of prospective memory: a meta-analysis and the "Attention to Delayed Intention" (AtoDI) model. Neuroscience \& Biobehavioral Reviews, 52, 21-37.

Cona, G., \& Rothen, N. (2019). Neuropsychological and physiological correlates of prospective memory. In Rummel, J., \& McDaniel, M. A. (Eds), Prospective memory (pp. 95-115). Routledge.

Costa, A., Peppe, A., Caltagirone, C., \& Carlesimo, G. A. (2008). Prospective memory impairment in individuals with Parkinson's disease. Neuropsychology, 22(3), 283.

Crawford, J., Smith, G., Maylor, E., Della Sala, S., \& Logie, R. (2003). The Prospective and Retrospective Memory Questionnaire (PRMQ): Normative data and latent structure in a large non-clinical sample. Memory, 11(3), 261-275.

Crowe, S. F. (2008). The behavioural and emotional complications of traumatic brain injury. Psychology Press.

Ellis, J. A., \& Freeman, J. E. (2008). Ten years on: Realizing delayed intentions. In Kliegel, M., McDaniel, M. A., \& Einstein, G. O. (Eds), Prospective memory: Cognitive, neuroscience, developmental, and applied perspectives (pp. 1-27). Mahwah, NJ: Lawrence Erlbaum.

Fleming, J. M., Shum, D., Strong, J., \& Lightbody, S. (2005). Prospective memory rehabilitation for adults with traumatic brain injury: A compensatory training programme. Brain Injury, 19(1), 1-10.

Haslam, C., Batchelor, J., Fearnside, M. R., Haslam, S. A., Hawkins, S., \& Kenway, E. (1994). Post-coma disturbance and post-traumatic amnesia as nonlinear predictors of cognitive outcome following severe closed head injury: findings from the Westmead Head Injury Project. Brain Injury, 8(6), 519-528.

*Henry, J. D., Phillips, L. H., Crawford, J. R., Kliegel, M., Theodorou, G., \& Summers, F. (2007). Traumatic brain injury and prospective memory: Influence of task complexity. Journal of Clinical and Experimental Neuropsychology, 29(5), 457-466.

Henry, J. D., Rendell, P. G., Kliegel, M., \& Altgassen, M. (2007). Prospective memory in schizophrenia: Primary or secondary impairment? Schizophrenia Research, 95(1-3), 179-185.

Iverson, G. L. (2005). Outcome from mild traumatic brain injury. Current Opinion in Psychiatry, 18(3), 301-317.

Jeong, J. M., \& Cranney, J. (2009). Motivation, depression, and naturalistic time-based prospective remembering. Memory, 17(7), 732-741.

Jones, S., Livner, Å., \& Bäckman, L. (2006). Patterns of prospective and retrospective memory impairment in preclinical Alzheimer's disease. Neuropsychology, 20(2), 144.

Kerns, K. A., \& Price, K. J. (2001). An investigation of prospective memory in children with ADHD. Child Neuropsychology, 7(3), 162-171.

*Kinch, J., \& McDonald, S. (2001). Traumatic brain injury and prospective memory: An examination of the influences of executive functioning and retrospective memory. Brain Impairment, 2(2), 119-130.

*Kinsella, G. J., Ong, B., \& Tucker, J. (2009). Traumatic brain injury and prospective memory in a virtual shopping trip task: Does it matter who generates the prospective memory target? Brain Impairment, 10(1), 45-51.

Kliegel, M., Martin, M., McDaniel, M. A., \& Einstein, G. O. (2002). Complex prospective memory and executive control of working memory: A process model. Psychological Test and Assessment Modeling, 44(2), 303.

Kliegel, M., Jager, T., Altgassen, M., Shum, D. (2012). Clinical Neuropsychology of Prospective Memory. In Kliegel, M., McDaniel, M. A., \& Einstein, G. O. (Eds), Prospective memory: Cogni- 
tive, neuroscience, developmental, and applied perspectives (pp. 283-308). Mahwah, NJ: Lawrence Erlbaum.

*Knight, R. G., Harnett, M., \& Titov, N. (2005). The effects of traumatic brain injury on the predicted and actual performance of a test of prospective remembering. Brain Injury, 19(1), $19-27$.

*Knight, R. G., Titov, N., \& Crawford, M. (2006). The effects of distraction on prospective remembering following traumatic brain injury assessed in a simulated naturalistic environment. Journal of the International Neuropsychological Society, 12(1), 8-16.

Kvavilashvili, L. (1987). Remembering intention as a distinct form of memory. British Journal of Psychology, 78(4), 507-518.

Kvavilashvili, L. (1992). Remembering intentions: A critical review of existing experimental paradigms. Applied Cognitive Psychology, 6(6), 507-524.

Kvavilashvili, L., \& Ellis, J. (1996). Varieties of intention: Some distinctions and classifications. In Brandimonte, M., Einstein, G. O., \& McDaniel, M. A. (Eds), Prospective memory: Theory and applications (pp. 23-52). Mahwah, NJ: Lawrence Erlbaum.

*Lajeunesse, A., Potvin, M. J., Audy, J., Paradis, V., Giguère, J. F., \& Rouleau, I. (2019). Prospective memory assessment in acute mild traumatic brain injury. The Clinical Neuropsychologist, $33(7), 1175-1194$.

Levin, H. S. \& Krauss, M. F. (1994). The frontal lobes and traumatic brain injury. Journal of Neuropsychiatry and Clinical Neuroscience, 6, 433-454.

Levin, H. S., Hanten, G. (2004). Posttraumatic Amnesia and Residual Memory Deficit after Closed Head Injury. In Baddeley, A. D., Kopelman, M., \& Wilson, B. A. (Eds), The essential handbook of memory disorders for clinicians (pp. 37-67). John Wiley \& Sons.

Marshman, L. A., Jakabek, D., Hennessy, M., Quirk, F., \& Guazzo, E. P. (2013). Post-traumatic amnesia. Journal of Clinical Neuroscience, 20(11), 1475-1481.

Martin, M., Kliegel, M., \& McDaniel, M. A. (2003). The involvement of executive functions in prospective memory performance of adults. International Journal of Psychology, 38(4), 195-206.

*Mathias, J. L., \& Mansfield, K. M. (2005). Prospective and declarative memory problems following moderate and severe traumatic brain injury. Brain Injury, 19(4), 271-282.

*Maujean, A., Shum, D., \& McQueen, R. (2003). Effect of cognitive demand on prospective memory in individuals with traumatic brain injury. Brain Impairment, 4(2), 135-145.

McDaniel, M. A., \& Einstein, G. O. (2000). Strategic and automatic processes in prospective memory retrieval: A multiprocess framework. Applied Cognitive Psychology: The Official Journal of the Society for Applied Research in Memory and Cognition, 14(7), 127-144.

McDonald-Miszczak, L., Gould, O. N., \& Tychynski, D. (1999). Metamemory predictors of prospective and retrospective memory performance. The Journal of General Psychology, 126(1), $37-52$.

Meacham, J. A., \& Dumitru, J. (1976). Prospective remembering and external retrieval cues. Catalog of Selected Documents in Psychology, 6(65), Ms. No. 1284.

Meacham, J. A., \& Singer, J. (1977). Incentive effects in prospective remembering. The Journal of Psychology, 97(2), 191-197.

Miller, E. K., \& Cohen, J. D. (2001). An integrative theory of prefrontal cortex function. Annual Review of Neuroscience, 24(1), 167-202.

*Mioni, G., Stablum, F., McClintock, S. M., \& Cantagallo, A. (2012). Time-based prospective memory in severe traumatic brain injury patients: The involvement of executive functions and time perception. Journal of the International Neuropsychological Society, 18(4), 697-705. 
*Mioni, G., Rendell, P. G., Henry, J., Cantagallo, A., \& Stablum, F. (2013). An investigation of prospective memory functions in people with traumatic brain injury using Virtual Week. Journal of Clinical and Experimental Neuropsychology, 35(6), 617-630.

*Mioni, G., Rendell, P. G., Terrett, G., \& Stablum, F. (2015). Prospective memory performance in traumatic brain injury patients: a study of implementation intentions. Journal of the International Neuropsychological Society, 21(4), 305-313.

*Mioni, G., Bertucci, E., Rosato, A., Terrett, G., Rendell, P. G., Zamuner, M., \& Stablum, F. (2017). Improving prospective memory performance with future event simulation in traumatic brain injury patients. British Journal of Clinical Psychology, 56(2), 130-148.

Miyake, A., Friedman, N. P., Emerson, M. J., Witzki, A. H., Howerter, A., \& Wager, T. D. (2000). The unity and diversity of executive functions and their contributions to complex "frontal lobe" tasks: A latent variable analysis. Cognitive Psychology, 41(1), 49-100.

*O'Brien, K. H., \& Kennedy, M. R. (2018). Predicting Remembering: Judgments of Prospective Memory After Traumatic Brain Injury. Journal of Speech, Language, and Hearing Research, 61(6), 1393-1408.

Okuda, J., Fujii, T., Ohtake, H., Tsukiura, T., Yamadori, A., Frith, C. D., \& Burgess, P. W. (2007). Differential involvement of regions of rostral prefrontal cortex (Brodmann area 10) in time-and event-based prospective memory. International Journal of Psychophysiology, 64(3), 233-246.

*Palermo, L., Cinelli, M. C., Piccardi, L., De Felice, S., Ciurli, P., Incoccia, C., et al (2020). Cognitive functions underlying prospective memory deficits: A study on traumatic brain injury. Applied Neuropsychology: Adult, 27(2), 158-172.

*Pavawalla, S. P., Schmitter-Edgecombe, M., \& Smith, R. E. (2012). Prospective memory after moderate-to-severe traumatic brain injury: A multinomial modeling approach. Neuropsychology, 26(1), 91 .

*Potvin, M. J., Rouleau, I., Audy, J., Charbonneau, S., \& Giguère, J. F. (2011). Ecological prospective memory assessment in patients with traumatic brain injury. Brain Injury, 25(2), 192-205.

Rabbitt, P. (Ed.) (2004). Methodology of frontal and executive function. Psychology Press.

Racsmány, M., \& Kónya, A. (1998). A Rivermead Viselkedéses Memória Teszt Magyar Változat. Thames Valley Test Company.

Racsmány, M., Demeter, G., Csigó, K., Harsányi, A., \& Németh, A. (2011). An experimental study of prospective memory in obsessive-compulsive disorder. Journal of Clinical and Experimental Neuropsychology, 33(1), 85-91.

Raskin, S. A. (2004). The Memory for Intentions Screening Test. Journal of the International Neuropsychological Society, 10(1), 110.

*Raskin, S. A., Shum, D. H. K., Ellis, J., Pereira, A., \& Mills, G. (2017). A comparison of laboratory, clinical, and self-report measures of prospective memory in healthy adults and individuals with brain injury. Journal of Clinical and Experimental Neuropsychology, 40(5), 423-436.

Raskin, S. A., Williams, J., \& Aiken, E. M. (2018). A review of prospective memory in individuals with acquired brain injury. The Clinical Neuropsychologist, 32(5), 891-921.

Rehel, S., Legrand, N., Lecouvey, G., Laniepce, A., Bertran, F., Fleury, P., et al (2019). Effects of Sleep and Age on Prospective Memory Consolidation: A Walk in a Virtual Museum. Clocks \& Sleep, 1(3), 332-351.

Rendell, P. G., Gray, T. J., Henry, J. D., \& Tolan, A. (2007). Prospective memory impairment in “ecstasy"(MDMA) users. Psychopharmacology, 194(4), 497-504.

Rendell, P. G., \& Henry, J. D. (2009). A review of Virtual Week for prospective memory assessment: Clinical implications. Brain Impairment, 10(1), 14-22. 
Rose, N. S., Rendell, P. G., Hering, A., Kliegel, M., Bidelman, G. M., \& Craik, F. I. (2015). Cognitive and neural plasticity in older adults' prospective memory following training with the Virtual Week computer game. Frontiers in Human Neuroscience, 9, 592.

Rude, S. S., Hertel, P. T., Jarrold, W., Covich, J., \& Hedlund, S. (1999). Depression-related impairments in prospective memory. Cognition E्E Emotion, 13(3), 267-276.

Schretlen, D., \& Shapiro, A. M. (2003). A quantitative review of the effects of traumatic brain injury on cognitive functioning. International Review of Psychiatry, 15, 341-349.

*Schmitter-Edgecombe, M., \& Wright, M. J. (2004). Event-based prospective memory following severe closed-head injury. Neuropsychology, 18(2), 353.

Scullin, M. K., Bugg, J. M., \& McDaniel, M. A. (2012). Whoops, I did it again: Commission errors in prospective memory. Psychology and Aging, 27(1), 46.

*Shum, D., Valentine, M., \& Cutmore, T. (1999). Performance of individuals with severe long-term traumatic brain injury on time-, event-, and activity-based prospective memory tasks. Journal of Clinical and Experimental Neuropsychology, 21(1), 49-58.

Shum, D., Levin, H., \& Chan, R. C. (2011). Prospective memory in patients with closed head injury: A review. Neuropsychologia, 49(8), 2156-2165.

Simons, J. S., Schölvinck, M. L., Gilbert, S. J., Frith, C. D., \& Burgess, P. W. (2006). Differential components of prospective memory? Evidence from fMRI. Neuropsychologia, 44(8), $1388-1397$

Smith, R. E. (2003). The cost of remembering to remember in event-based prospective memory: investigating the capacity demands of delayed intention performance. Journal of Experimental Psychology: Learning, Memory, and Cognition, 29(3), 347.

Smith, R. E. (2010). What costs do reveal and moving beyond cost: Reply to Einstein and McDaniel (2010). Journal of Experimental Psychology: Learning, Memory, and Cognition, 36, 1089-1095.

Spiess, M. A., Meier, B., \& Roebers, C. M. (2015). Prospective memory, executive functions, and metacognition are already differentiated in young elementary school children. Swiss Journal of Psychology, 74(4), 229-241.

*Tay, S. Y., Ang, B. T., Lau, X. Y., Meyyappan, A., \& Collinson, S. L. (2010). Chronic impairment of prospective memory after mild traumatic brain injury. Journal of Neurotrauma, 27(1), $77-83$.

Tagliaferri, F., Compagnone, C., Korsic, M., Servadei, F., \& Kraus, J. J. A. N. (2006) . A systematic review of brain injury epidemiology in Europe. Acta Neurochirurgica, 148(3), 255-268.

Wilson, B., Cockburn, J., \& Baddeley, A. (1985). Manual for the Rivermead Behavioural Memory Test. London: Thames Valley Test Company, Suffolk, England.

Wilson, B. A. (2004). Management and Remediation of Memory Problems in Brain-injured Adults. In Baddeley, A. D., Kopelman, E. D., Wilson, B. A. (Eds), The Essential Handbook of Memory Disorders for Clinicians (pp. 199-226). Chichester: John Wiley \& Sons.

Wilson, B. A., Emslie, H., Foley, J., Shiel, A., \& Watson, P. H. K. (2005). The Cambridge Prospective Memory Test. London: Harcourt Assessment.

Wong Gonzalez, D., \& Buchanan, L. (2019). A meta-analysis of task-related influences in prospective memory in traumatic brain injury. Neuropsychological Rehabilitation, 29(5), 657-671.

World Health Organization (2006). Neurological disorders: public health challenges. World Health Organization. Letöltve: 2020.12.03-án: www.who.int/mental_health/neurology/neurodiso/ en/ 


\section{PROSPECTIVE MEMORY AND TRAUMATIC BRAIN INJURY: A REVIEW}

\section{LENCSÉS, ANITA - DEMETER, GYULA}

To the best of our knowledge, the present paper is the first review in Hungarian on the topic of prospective memory (PM), and it has a dual objective. On the one hand, it summarizes the most important concepts, theories, experimental and neuroscientific results of PM, describing the clinical relevance of the research. PM refers to the memory for future intentions, and it is a complex cognitive ability that is essential in performing our day-to-day tasks. PM function is related to the prefrontal cortex and its connections, and its dysfunction is well-documented in several diseases affecting the frontostriatal system. This review focuses on traumatic brain injury, a common neurological disorder. Patients with traumatic brain injury experience PM dysfunction, which is a common and persistent cognitive disorder making their everyday life the most difficult. Nevertheless, little research has investigated the factors contributing to decreased PM performance in this patient population, and the results are contradictory.

Another goal of our study is to summarize empirical research on PM performance after traumatic brain injury. In this literature review, we identified 25 empirical studies comparing the PM performance of adults with traumatic brain injury with those of healthy controls. Based on these empirical results, PM dysfunction is a common finding after traumatic brain injury. However, a number of factors can affect PM performance in this population: the severity and localization of injury, time spent in coma, length of posttraumatic amnesia, time since injury, mood disorders and comorbid cognitive disorders, and task characteristics, such as the type of measurement, the components of the PM task, and features of the PM cue and the ongoing task.

In our opinion, these findings not only provide essential conclusions about understanding the functioning of PM, but they can also establish the foundation for rehabilitation and therapeutic work, and contribute to the creation of an effective cognitive training focused on PM for traumatic brain injury patients.

Keywords: prospective memory, delayed intentions, traumatic brain injury, rehabilitation

A cikk a Creative Commons Attribution 4.0 International License (https://creativecommons. org/licenses/by/4.0) feltételei szerint publikált Open Access közlemény, melynek szellemében a cikk bármilyen médiumban szabadon felhasználható, megosztható és újraközölhető, feltéve, hogy az eredeti szerzó és a közlés helye, illetve a CC License linkje és az esetlegesen végrehajtott módosítások feltüntetésre kerülnek. (SID_1) 